NBER WORKING PAPER SERIES

\title{
DEFINED CONTRIBUTION PLANS, DEFINED BENEFIT PLANS, AND THE ACCUMULATION OF RETIREMENT WEALTH
}

\author{
James Poterba \\ Joshua Rauh \\ Steven Venti \\ David Wise \\ Working Paper 12597 \\ http://www.nber.org/papers/w12597 \\ NATIONAL BUREAU OF ECONOMIC RESEARCH \\ 1050 Massachusetts Avenue \\ Cambridge, MA 02138 \\ October 2006
}

We are extremely grateful to Tonja Bowen for extraordinary and tireless research assistance, to Gary Engelhardt and Anil Kumar for graciously providing us with tabulations from their HRS Defined Contribution Plan imputation algorithm, to Paul Bingley, Peter Diamond, Gary Engelhardt, Jon Gruber, Helena Stolyarova, and many seminar participants for helpful comments, and to the National Institute of Aging for research support under grant number P01 AG005842. The views expressed herein are those of the author(s) and do not necessarily reflect the views of the National Bureau of Economic Research.

(C) 2006 by James Poterba, Joshua Rauh, Steven Venti, and David Wise. All rights reserved. Short sections of text, not to exceed two paragraphs, may be quoted without explicit permission provided that full credit, including $\odot$ notice, is given to the source. 
Defined Contribution Plans, Defined Benefit Plans, and the Accumulation of Retirement Wealth James Poterba, Joshua Rauh, Steven Venti, and David Wise

NBER Working Paper No. 12597

October 2006

JEL No. J14,J26,J32

\begin{abstract}
$\underline{\text { ABSTRACT }}$
The private pension structure in the United States, once dominated by defined benefit (DB) plans, is currently divided between defined contribution (DC) and DB plans. Wealth accumulation in DC plans depends on the participant's contribution behavior and on financial market returns, while accumulation in DB plans is sensitive to a participant's labor market experience and to plan parameters. This paper simulates the distribution of retirement wealth, as well as the average level of such wealth, under representative DB and DC plans. The analysis considers the role of asset returns, earnings histories, and retirement plan characteristics using data from the Health and Retirement Study (HRS). To simulate wealth in DC plans, individuals are randomly assigned a share of wages that they and their employer contribute to the plan. The analysis considers several possible asset allocation strategies, with asset returns drawn from the historical return distribution. The DB plan simulations draw earnings histories from the HRS, and randomly assign each individual a pension plan drawn from a sample of large private and public defined benefit plans. The simulations yield distributions of both DC and DB wealth at retirement as well as estimates of the certainty-equivalent wealth associated with representative DB and DC pension structures. The results suggest that average retirement wealth accruals under current DC plans exceed average accruals under private sector DB plans, although the heterogeneity in both types of plans implies many deviations from this rule. The comparison of current DC plans with more generous public sector DB plans is less definitive, because public sector DB plans are more generous on average than their private sector counterparts. The ranking of the expected value of retirement wealth accruals, and the certainty equivalent of those accruals, for these two classes of plans is sensitive to assumptions about the asset allocation rules of the DC plan participant.
\end{abstract}

James Poterba

Department of Economics

MIT, E52-350

50 Memorial Drive

Cambridge, MA 02142-1347

and NBER

poterba@mit.edu

Joshua Rauh

Graduate School of Business

University of Chicago

5807 S. Woodlawn Avenue

Chicago, IL 60637

and NBER

jrauh@ChicagoGSB.edu

\author{
Steven Venti \\ Department of Economics \\ 6106 Rockefeller Center \\ Dartmouth College \\ Hanover, NH 03755 \\ and NBER \\ steven.f.venti@dartmouth.edu \\ David Wise \\ NBER \\ 1050 Massachusetts Avenue \\ Cambridge, MA 02138-5398 \\ and NBER \\ dwise@nber.org
}


Private retirement arrangements in the United States were once predominantly defined benefit (DB) pension plans, but in the last two decades, there has been a shift toward defined contribution (DC) arrangements. Very few firms have created new DB plans, while many firms have moved toward greater reliance on DC plans, particularly for new workers. Rapidly expending industries, such as software development, have relied on DC rather than DB plans to provide for employee retirement. The growth of DC plans has given employees new responsibility for managing retirement assets and made retirement wealth accumulation a function of an employee's contribution and asset allocation decisions.

Accrued benefits in defined benefit plans do not depend on financial market returns, except in extreme circumstances that correspond to an insolvent DB plan. Yet benefits in DC plans are tied directly to financial market returns. Some analysts have suggested that DC plans expose prospective retirees to greater risk than DB plans precisely because of this financial market link. Several recent studies have examined the financial market risk in DC plans and the role of asset allocation choices in controlling this risk. Shiller (2005) examines a variety of asset allocation rules in the context of studying a private accounts Social Security system. Poterba, Rauh, Venti, and Wise (2005a) examine how age-related adjustments in asset allocation such as those that "lifecycle" mutual funds affect the distribution of DC plan balances at retirement. These studies, and others, highlight the importance of net-of-expense asset returns over the course of a DC plan participant's working life, asset allocation, and the participant's contribution rate in determining the plan balance at retirement. They also demonstrate the potential dispersion in DC plan values at retirement that can be attributed to financial market returns.

Just because a participant's accumulation in a DC plan is risky, however, does not imply that typical DC plan is riskier than a typical DB plan. Research on DB plans has long recognized that retirement accumulations in these plans are uncertain from the participant's perspective, but relatively few studies have tried to compare the risks of DC and DB plans. Balcer and Sahin (1979) use a lifetime perspective to make such comparisons, recognizing that earnings uncertainty and job transitions have an important effect on the accumulated wealth of DB plan participants. Bodie, Marcus, and Merton (1988) observe that DB and DC plans entail different risks from the standpoint of participants, but they 
emphasize that both plan types are risky. While DC plan participants face asset market risk, DB plan participants largely avoid such risk. Benefits are a liability of the sponsoring firm and they are not affected by the rate of return on plan assets except when the plan closes or the firm goes bankrupt because of prospective liabilities. Nevertheless, shocks to earnings, job changes, and early retirement can all affect the value of DB plan accruals. So can the variation across employers in specific DB plan provisions, which affect post-retirement benefits.

The complex interaction between pension plan accruals in DB and DC plans, financial market returns, and worker employment experience makes it difficult to compare the relative risks of these plans in a systematic fashion. Two recent studies have taken important steps to address this issue. The first, Samwick and Skinner (2004), uses data from the 1983 and 1989 Survey of Consumer Finances and Pension Provider Supplement (PPS) to summarize the set of DC and DB plans in the workplace. They find that for many workers the accumulation of assets in DC plans is likely to exceed the actuarial present value of the benefit entitlements that they would accrue in a DB plan. The findings suggest important differences between DB and DC plans. However, the underlying data were collected early in the expansion of the DC sector, so they may not describe current pension offerings. Moreover, the SCF lacks information on individual earnings histories, so Samwick and Skinner (2004) generate synthetic earnings histories and evaluate DB payouts and DC asset accumulation for each such earnings history. They assume that the logarithm of earnings follows a random walk with an age-related drift component. This approach is unlikely to capture the subtle stochastic properties of actual earnings histories, or to reflect the discrete risk of job loss or job change at various ages. The present study uses individual earnings histories to examine the value of DB and DC benefits.

The second study, Schrager (2005), examines the same set of issues using data on earnings and job change patterns from the Panel Survey of Income Dynamics. This study does rely on individual earnings histories, although the sample of older workers in the PSID is modest. This study makes the important point that job turnover increased in the 1990s relative to earlier decades. Higher job turnover makes DC plans more attractive relative to DB plans for many workers. This study suggests that DC 
plans may offer greater opportunities for retirement wealth accumulation than DB plans for many workers. It integrates optimal consumption planning with the presence of pension arrangements, which makes it possible to investigate household responses to the presence of a DC rather than a DB plan. However, solving the lifecycle planning problem requires parameterizing the earnings and job change processes, thereby suppressing the richness that individual-specific earnings histories offer.

This paper moves beyond the existing studies of wealth accumulation in DB and DC plans. It draws on lifetime earnings histories from the Health and Retirement Study to capture individual-level heterogeneity in age-earnings profiles and in job transitions. It employs historical asset return distributions to simulate the distribution of financial outcomes for DC plan participants with various asset allocation patterns. The analysis yields a distribution of retirement wealth outcomes for both DB and DC plan participants. These distributions can be summarized using the expected present discounted value of DB plan payouts at a given age, and the value of DC plan accumulations at the same age. While estimates of DB wealth accumulation are sensitive to assumptions about prospective discount rates and mortality rates, and they are likely to be measured with error, they nevertheless provide some guidance on the relative magnitude of accumulations in DB and DC plans.

The paper is divided into six sections. The first summarizes the ongoing shift from DB to DC plans and presents aggregate information on participation in these plans as well as cohort-specific data on participation rates. Section two describes the sample of HRS households that we use to evaluate retirement wealth accumulation under DC and DB plans. It also describes the DC plans that these households participate in, with particular attention to the share of salary that employers and employees contribute to the plan. The third section describes the algorithm that we use to simulate the distribution of DC retirement plan assets; it draws substantially on Poterba, Rauh, Venti, and Wise (PRVW) (2005a, 2005b). Section four describes our algorithm for computing wealth accumulation in DB plans, which draws heavily on programs developed for HRS users by the Survey Research Center. It also explains how we impute job transitions to HRS respondents, and summarizes the resulting distribution of job lengths. The fifth section presents our central findings on the distributions of DC and DB plan accumulations for a 
sample of representative DC and DB plans. We present averages, which aggregate over workers with different earnings trajectories and plans with different design characteristics, as well as richer information on the distribution of wealth outcomes. We also compute certainty equivalent measures of the value of participating in DC and DB plans under various assumptions about individual risk aversion. There is a brief conclusion.

\section{Recent Evolution of DC and DB Pension Plans}

Both the number of private sector DC plans and the number of workers covered by these plans have expanded rapidly in the last two decades, while the number of workers covered by DB plans has been stable or falling. Workers covered by DB plans are increasingly concentrated in the public sector. Table 1 presents summary information on the number of vested participants in private sector DB and DC plans from 1990 to 2003. The table relies on Buessing and Soto's (2006) analysis of data from Department of Labor Form 5500 filings. The data are adjusted for the presence of non-vested and nonparticipating employees and for the double-counting of employees who may be enrolled in both DC and DB plans at the same firm. The data show a decline in the number of individuals who participate only in a private sector DB plan, from 9.6 million in 1990 to 6.6 million in 2003. The number of individuals with both types of plans is roughly constant over this time period, at nearly 14 million. The number of private sector employees with only DC coverage has risen dramatically from 11.5 million to 30.1 million since 1990. While the data sample ends in 2003, it is likely that in subsequent years, the number of DB plan participants continued to decline. Many firms have "frozen" DB plans during this period; Munnell, Golub-Sass, Soto, and Vitagliano (2006) describe this development.

Most public sector pension plans in the U.S. are still DB plans. The U.S. Census Bureau (2006) reports 2,659 federal, state, and local pension systems in the U.S., covering 17.9 million workers. Although the Census does not collect detailed data on plan type, some information can be obtained from the Pensions and Investments survey of the 1000 largest pension plans. In 2004, 224 of these plans were public sector plans, and DB assets represented 89.3 percent of total public pension assets. Among public sector plans, 62 percent reported zero DC assets, and 89 percent reported DC assets of less than one fifth 
of combined DB and DC assets. These figures are almost identical to those from the first Pensions and Investments survey in 1997. In that year, there were 217 public sector plans and DB assets also represented 89.3 percent of total public pension assets. Among public sector plans, 64 percent reported no DC assets, and 89 percent reported that less than one fifth of their assets were in DC plans.

Aggregate statistics provide some information on the shifting pension structure in the U.S. labor market. An alternative way to document shifting DB coverage involves the comparison of household survey data from various years. We study data from the Survey of Income and Program Participation (SIPP) for the years 1984, 1987, 1991, 1993, 1995, 1998, and 2003. Figure 1a shows the DB participation rate for selected birth cohorts in various years. By organizing the data by birth cohort, we can track a cohort as it ages and moves through the lifecycle labor market experience. The DB participation rate at a given age has declined over time. For example, it was 51 percent for 45 -year-olds in 1984 and 31 percent for 45-year-olds in 2002. Comparisons at other ages show similar differences.

Figure 1a shows a cohort effect in DB participation rates. Younger cohorts have successively lower participation rates at all ages. There is also a within-cohort decline in the DB participation rate with age. The within-cohort decline for older cohorts is attributable in part to the retirement of DB plan participants. Ceteris paribus, DB participants tend to retire earlier than DC participants, because of the declining rate of retirement benefit accrual in many DB plans. Friedberg and Webb (2005) document the impact of DB vs. DC pension structure on retirement rates, and support this conclusion. Thus the share of the employed population enrolled in DC plans is likely to rise as the labor force participation rate declines at older ages. Even for younger cohorts, however, there is typically a decline in DB participation rates after 1987 or 1989, which reflects the movement away from these plans in the private sector.

Figure $1 \mathrm{~b}$ shows cohort participation rates in DC plans. It shows that younger cohorts have higher age-specific DC participation rates than older cohorts. For example, 45-year olds in 1984 had only an 8 percent participation rate, compared with 45 percent for 45 -year-olds in 2002. Furthermore, within cohorts, DC participation rates rise sharply with age, at least until individuals begin to retire and cash out of these plans. The cohort that was 27 years old in 1984 had only a four percent DC participation rate in 
that year, compared to 45 percent participation rate in 2002. The cohort that was 45 years old in 1984 had an 8 percent participation rate in 1984 , but a 38 percent participation rate when the cohort members were 59 in 1998 . By age 64 , however, this cohort's participation rate had declined to 33 percent, reflecting the cash-out behavior described above.

The data presented in Figures 1a and 1b clearly suggest that a growing fraction of the workforce is accumulating retirement wealth through DC plans, while DB coverage is stable or declining. Friedberg and Owyang (2005) cite several potential explanations for this change in pension structure. The balance of this paper considers the implications of this trend for the average level of pension wealth at retirement, and for the dispersion of this wealth.

\section{Selecting a Sample of HRS Households for Analyzing DC and DB Plan Risks}

We use individual earning histories in the HRS along with data on DB and DC plans in the 1990s to evaluate pension wealth accumulation. Using actual earnings histories makes it difficult to find optimal lifetime consumption paths for individuals, because we cannot distill future earnings risk to an easily-parameterized stochastic process. Nevertheless, using actual earnings histories enables us to capture elements of DC and DB pension risk that are lost with simpler earnings processes.

We focus on married couples both because the modal individual in the pre-retirement cohort is married - nearly 70 percent of retirement-age individuals are married - and to avoid the heterogeneity that arises in the single population, where some individuals have never married and have quite different financial circumstances than individuals who have lost a spouse. We impose several other restrictions in selecting our sample, in particular the presence of usable data for several key data items.

Table 2 presents information on the sample selection criteria that we employ and their impact on our sample size. Our sample includes all HRS couples headed by men aged 63-72 in 2000 for whom we could obtain links to Social Security earnings histories. There are 3,833 HRS households with Social Security earnings histories. The restriction to couples eliminates approximately 44 percent of that sample, and the age restriction removes an additional 19 percent, leaving a sample of 1,400 households. We impose our age restriction because including those younger than 62 would require extrapolating earnings 
histories for the latter part of the working career, and including those over 73 would make it difficult to calibrate their financial circumstances at retirement age. We focus on the earnings experience and the pension benefits for the husband in each married couple because their earnings histories have fewer interruptions than the earnings histories of their wives. In future work we hope to explore the extent to which our sample restrictions make the group that we analyze unrepresentative of the broader population.

\subsection{Measuring Earnings Histories}

HRS respondents' earnings records consist of different earnings measures in different years beginning in 1951. For the period 1951-1991, the HRS includes Social Security earnings records for a subset of respondents; our subsample is drawn exclusively from this group. These data show exact earnings only for those with earnings below the Social Security payroll tax threshold. For those with higher earnings, the data simply show the threshold amount. This top-coding problem undermines the usefulness of the SSA data. For the years after 1991, the HRS includes self-reported total earnings for each member of each HRS household. For the years between 1980 and 1990, W-2 earnings records from the Internal Revenue Service have been linked to HRS survey records. While W-2 filings exclude some components of income, such as earnings from self-employment, they are likely to dominate the Social Security earnings data that are also available for these years because they are not top-coded.

The taxable maximum earnings level for Social Security has varied over time, and so has the dispersion of earnings, so the fraction of earnings that are not captured on Social Security records varies from year to year. For high-income subsets of workers, however, such as those with a college education, the earnings cap is a substantial impediment to measuring lifetime contributions to a DC plan or the stream of earnings that may generate benefits in a DB plan. Table 3 shows the fraction of sample participants, stratified by various characteristics, who are affected by the earnings cap in years between 1951 and 1979. The data show that in some years in the early 1970s, particularly for college-educated respondents, more than half of HRS respondents had top-coded earnings. Because the payroll tax cap was not indexed for inflation during much of this period, and it changed as a result of legislative action, the real value of the threshold varied over time and occasionally experienced sharp changes. 
Using top-coded earnings data to impute either DC plan contributions or accruing DB benefits would systematically understate pension wealth for high earners. To remedy this problem, we "correct" top-coded earnings by replacing the top-code amount with an estimate of the conditional mean earnings for a respondent, conditional on earnings exceeding the top-code. We estimate cross-sectional tobit equations for each year prior to 1980 using the reported Social Security earnings for men in our sample, with individual characteristics such as age and education as explanatory variables. In the years when a substantial fraction of individuals are affected by the top-code, we find estimated tobit coefficients that are sensitive to the set of observations in the estimation subsample. In particular, including men with low earnings leads to "corrected" earnings for those at the payroll tax cap that are substantially higher than the earnings cap, regardless of other individual attributes. The results are more robust when respondents with very low earnings, for example those with earnings below \$2500 (in \$2000), are excluded from our sample. We impose this sample restriction in our tobit analysis; detailed results are available on request.

We summarize our top-coding corrected results by showing the imputed age-earnings profile that emerges from our analysis. Figures $2 \mathrm{a}$ through $2 \mathrm{c}$ show the mean age-earnings profile for three different education sub-groups: less than high school, high school and some college, and college and beyond, after we correct for top-coding. The median earnings path, displayed in Figure 2b, shows an unusual "bump" in early middle age. This appears to be due to the top-coding adjustment for years in which an especially high fraction of workers were affected by the taxable earnings cap. This unusual pattern does not appear at the $25^{\text {th }}$ or $75^{\text {th }}$ percentiles, nor does it occur when we plot the means of the adjusted earnings histories. We suspect that this is because there is less variation over time in the fraction of workers affected by the tax cap at these percentiles than at the median.

Other researchers have tackled the top-coding problem differently. Scholz, Seshadri, and Khitatrakun (2006), for example, develop an alternative algorithm that exploits the intertemporal dependence of earnings as well as distributional assumptions to adjust top-coded earnings records. They estimate cross-sectional wage equations using W-2 data as well as SSA earnings records, and then backcast the residual from the years with W-2 data to adjust the SSA data for earlier years. Because HRS 
respondents fall in a relatively narrow age range, however, this procedure essentially uses the serial correlation structure from earnings in mid-life and the years approaching retirement to adjust earnings at an earlier part of the lifecycle. This algorithm's validity depends on the maintained assumption that this correlation structure is stable; our algorithm makes no such assumption. The shortcoming of our approach is that it does not capture the persistence of earnings for a given individual through time.

\subsection{Retiree Wealth for HRS Households}

The HRS provides detail on the value of respondents' DC and DB wealth in various survey years. Before simulating the wealth of retires who work for their entire career under particular sets of DB or DC rules, we summarize the pension wealth imputations provided by version 1.0 of the HRS pension wealth calculator described by Peticolas and Stolyarova (2003). The HRS pension wealth estimates combine information from respondents with data provided by employers. The HRS pension wealth estimates have been widely used, and there is a substantial literature on the strengths and weaknesses of these data. Gustman, Mitchell, Samwick, and Steinmeier (2000) and Rohwedder (2003) provide a broader introduction to the measurement of pension wealth in household data, with particular discussion of the HRS. Cunningham, Engelhardt, and Kumar (CEK) (2006) develop an improved algorithm for imputing wealth to DC plan participants. We build on several of their suggestions in our work below, although we do not employ their estimates of DC wealth for HRS participants.

The various components of pension wealth are available for HRS respondents, although in some cases we need to work to make the data applicable to a constant age for all survey participants. The HRS collects data every other year, so our procedures focus on households headed by individuals in two year age spans. For DC plan balances, the HRS includes a self-reported balance. Notwithstanding previous concerns, such as those voiced in Gustman and Steinmeier (2004), that self-reported data are more prone to measurement error than are data from providers, we rely on this information. We use the balance at age 63 or 64 for those who are this age in 2000, and we adjust the plan balances for those who are older and younger in 2000 by imputing a rate of return to DC assets. For HRS respondents who are 63 or 64 in one of the survey years, and who are covered by a DB plan, we compute DB wealth for a retirement age 
of 62 using the HRS Pension Calculator. This equals the present discounted value of future pension benefits assuming this retirement age. We then "age" this present value by one year, to age 63 , using a three percent real interest rate. This three percent value is the real interest rate assumed in the intermediate scenario of the Social Security Administration. For Social Security wealth (SSW), we use cohort mortality tables and the SSA's intermediate-cost scenario discount rates to calculate the present discounted value of current or projected Social Security benefits when the husband is aged 63 or 64 . We normalize the value of the wife's Social Security to be the value when the husband is aged 63-64, assuming that Social Security payments start for the wife at age 62 if they have not started already. We value Social Security as a joint survivor annuity.

We also examine the non-retirement wealth of HRS households. We determine non-retirement wealth at age 63 using a procedure that varies depending on the household's age. For households headed by a husband who was either 63 or 64 in 1996, 1998 or 2000, there is a breakdown of non-pension wealth in HRS waves 3, 4, and 5. We scale all household wealth holdings to the 2000 base year, so that for each household we have an estimate of what their non-pension wealth would have been had they turned 63 in 2000. We implement this scaling by replacing the nominal returns on asset holdings in three categories financial wealth, housing equity, and other wealth - for the two years prior to the year in which the head of household was 63, with nominal returns on assets in these years in 1998 and 1999. As an example, this implies that we increase the value of non-retirement financial asset holdings for those who reached age 63-64 in 1996, because these individuals did not experience the strong and favorable asset market returns just before age 63 that were experienced by those who turned 63 in 1999 or 2000. PRVW (2005a) explains this procedure in more detail.

For HRS households with a head that was 63 or older in 1996, we impute wealth values for each asset class based on the median measured asset growth for households between the ages of 63 and 65, or 63 and 67, in the same educational category in later waves of the HRS. Thus our approach yields estimates of various components of the household balance sheet at age 63-64. We distinguish housing wealth from other wealth, because it is not clear whether housing wealth it should be viewed as a source 
of retirement wealth for elderly households. Venti and Wise (2001), who report that elderly households rarely draw down their housing wealth, argue against its inclusion in retirement wealth.

Table 4 shows mean, median, and various percentiles of the wealth distribution for the households associated with the married men in our sample. The mean total wealth for those in our sample, shown in the last horizontal panel, is $\$ 783,400$. There is substantial variation by education groups, with a mean of $\$ 1,324,500$ for those with at least a college education, and $\$ 468,100$ for those with less than a high-school degree. The tabulations show that there are substantial differences in wealth accumulation across households both within and across education categories. At most percentiles, the average wealth of a household that did not complete high school is no more than half that of a household that completed college. These differences are of the same magnitude as the differences between the $20^{\text {th }}$ and $60^{\text {th }}$ percentiles of the distribution for a given education level. The $80^{\text {th }}$ percentile of the distribution for all three education levels has wealth holdings that are at close to three times as great as those of households in the $20^{\text {th }}$ percentile for the same education level.

Although mean household net wealth is the sum of the means of the constituent parts, median and other quantile measures of the net worth distribution do not satisfy this property. Nevertheless we can offer some insights on the wealth distribution from the summary statistics in Table 4. For the group with less than a high school education, the present discounted value of Social Security benefits represents roughly half of household net worth, with net housing equity and other wealth in durables and related items accounting for nearly one fifth. On average, current DB and DC wealth values account for less than one tenth of household net worth for this group. For those in the college and beyond group, the present value of Social Security benefits accounts for less than a quarter of net worth, and other financial assets are the single most important component of net worth. DC wealth is substantially more important the DB wealth on average, with the mean DC accumulation, $\$ 330,900$, roughly five times greater than the mean DB wealth accumulation.

Mean wealth statistics are straightforward to analyze, but they often fail to capture the circumstances of households in much of the wealth distribution. The third panel of Table 4 shows that for 
the household at the median of the wealth distribution, net worth including Social Security wealth equals $\$ 536,800$. Nearly half of this amount takes the form of the present discounted value of expected Social Security payments and another twenty percent is accounted for by housing equity. The role of housing and Social Security wealth diminishes as we move to higher percentiles of the wealth distribution, or to households with more education, while other financial wealth becomes more significant. There is greater disparity in "other financial wealth" than in any other component of the household balance sheet. This wealth component is negligible at the $20^{\text {th }}$ percentile of the distribution, but by the $80^{\text {th }}$ percentile its value is $\$ 215,200$. The value of Social Security and annuity wealth varies least across percentiles of the distribution, reflecting the role of upper limits on benefit payments as well as minimum benefit payments.

For more than half of all sample participants, DB pension wealth is zero. At the $80^{\text {th }}$ percentile, individuals with high school and some college have $\$ 12,000$ in DB wealth and individuals with college or postgraduate degrees have DB wealth of $\$ 65,100$. Mean DB wealth accumulation for the entire sample is $\$ 47,700$. This is a comparison point we can use when examining the value of DB and DC plan assets that emerge in our simulations.

The net worth of households in our sub-sample of HRS households is greater than that of the entire HRS population, because we limit our attention to married couples. Our summary information also applies to 2000, while a number of earlier studies focused on HRS respondents in earlier years. Thus, we find substantially higher net worth than Moore and Mitchell (2000), who focus on all HRS households and find mean net worth in 1992 of $\$ 478,313$.

\section{Retirement Wealth Accumulation in DC Plans}

We now move from the summary of wealth information as recorded in the HRS to a simulation of wealth accumulation by households that are exposed to either DC or DB pensions throughout their working career. Our objective is to compute the mean level of retirement wealth, and the dispersion of such wealth, for a household with a realistic earnings trajectory and with exposure only to firms with DC plans, or only to employers with DB plans. In practice employees may experience shifts from employers 
with one type of plan to employers with another, but the presence of strong industry patterns in pension arrangements provides some support for our approach.

We model DC plan accumulation by simulating the path of plan contributions and investment returns over an individual's working life. We use actual lifetime earnings trajectories along with the historical distribution of returns on financial assets and realistic assumptions about the expenses charged by financial institutions that manage assets in defined contribution retirement plans to calculate the resulting asset balance at age 63. Our analysis has benefited substantially from CEK's (2006) work in developing an improved HRS DC/401(k) pension calculator. In particular, we follow CEK (2006) in using, where possible, information on elective deferrals as recorded on W-2 filings to determine DC plan contributions. Their analysis highlights the difficulties in evaluating pension wealth even for respondents in a survey like the HRS which was designed to collect data about financial conditions at retirement.

\subsection{Contribution Behavior}

We assume that an individual contributes a fixed percentage of his earnings to a DC plan each year during a working life that begins at age 28 . The contribution rate is determined by drawing from a distribution of combined employer and employee contribution as a percentage of pay for HRS males with positive DC contributions. We assume that this rate remains constant throughout an individual's career, so even when job changes occur, they involve a move to a new employer with the same contribution percentage. An alternative assumption, which we will examine in future simulation exercises, would

draw a random value of the total employer and employee contribution rate for each job that an individual holds. This would result in a less disperse distribution of retirement wealth outcomes than the one we report, but would have very little impact on the mean of wealth accumulation. The extent to which individual characteristics affect the overall contribution rate determines the plausibility of these alternative assumptions.

Table 5 shows the distribution of the share of earnings contributed by both employees and employers to DC plans for all men with positive DC contributions in our HRS sample. Following CEK (2006), the contribution rates are estimated using information from W-2 filings that are linked to HRS 
records. This approach relies on administrative data rather than self-reported contributor behavior, which CEK (2006) discover is a noisy measure of actual contributions. The disadvantage of this approach is that W-2 data cannot identify voluntary non-contributors, individuals who are eligible to make 401(k) contributions but choose not to do so. The lowest contribution rate we assign to DC plan participants is the mean combined contribution rate for the lowest decile of DC contributors, which is 1.9 percent of salary per year. We do not allow for the possibility that some workers covered by DC plans are not contributing to these plans. Simulations of DC wealth based on this distribution may therefore overstate wealth holdings at the bottom of the distribution. We nevertheless use these data because the estimates of the contribution rates throughout the distribution are likely to be more precise than those using other sources of data. Another option, which we do not pursue, would combine an estimate of the noncontribution rate for DC plan eligibles from self-reported data with the distribution of contribution rates conditional on a positive contributions in the W-2 data.

The mean contribution rate associated with the data in Table 5 is 8.3 percent, but there is substantial dispersion in contribution rates. The $25^{\text {th }}$ percentile value of the contribution rate is less than 5.3 percent, the median is approximately 7.7 percent, and the $75^{\text {th }}$ percentile value is greater than 10 percent. Ten percent of the individuals in DC plans have combined employer and employee contribution rates of at least 15 percent of salary, and ten percent have contribution rates of no more than three percent. We assume that each individual in our sample participates in the DC plan in every year in which he has Social Security earnings until age 63. Contributions are set to zero when the household is unemployed or retired. We assume that there are no contributions after age 63.

We denote each individual by subscript $i$, and denote his $\mathrm{DC}$ contribution at age a by $\mathrm{C}_{\mathrm{i}}(\mathrm{a})=$ $\mathrm{c}_{\mathrm{i}} * \mathrm{E}_{\mathrm{i}}(\mathrm{a})$ for $\mathrm{E}_{\mathrm{i}}(\mathrm{a})$ the individual's earnings at age a and $\mathrm{c}_{\mathrm{i}}$ the combined employer and employee contribution to the DC plan, as a percentage of earnings. We express this contribution in year 2000 dollars. We assume that contributions as a share of earnings are constant for each individual at all jobs that he holds. This amounts to assuming that when an individual changes jobs, he finds another employer with the same combined employer and employee contribution rate to the $401(\mathrm{k})$ as at the previous 
employer. This is an unlikely counterfactual. The other assumption that we could use in our simulations, that each job has a contribution fraction which is drawn from the distribution of contribution rates when an individual starts it, would eliminate any persistence in contribution fractions for a given individual from one job to the next. This also seems like an improbable counterfactual. Our assumption of a single contribution rate for the entire working career will result in a larger dispersion of retirement wealth outcomes than the alternative assumption, since randomization in contribution rates within the lifetime will move all workers toward average contribution rates.

To find the DC balance for an individual at age $63(\mathrm{a}=63)$, we cumulate contributions over the course of the working life with appropriate allowance for asset returns. Let $\mathrm{R}_{\mathrm{i}}(\mathrm{a})$ denote the net-ofexpense return earned on DC assets that were held at the beginning of the year when the participant attained age a. The value of the individual's DC assets at age 63 is then given by:

$$
W_{i}(63)=\sum_{t=0}^{35}\left\{\prod_{j=0}^{t}\left[1+R_{i}(63-j)\right]\right\} C_{i}(63-t)
$$

$\mathrm{R}_{\mathrm{i}}(\mathrm{a})$ depends on the year-specific returns on stocks and bonds, and on the mix of stocks and bonds that the individual owned at age a. If he holds an all-stock portfolio, then $R_{i}(a)=R_{\text {stock }}(a)$.

\subsection{Asset Allocation and Rate of Return Assumptions}

We assume that the three primary assets that individuals hold in their DC plans are corporate stock, nominal long-term government bonds, and inflation-indexed long-term bonds (TIPS). We do not consider the range of other investment opportunities that are increasingly available in 401(k)-type plans. Calibrating the returns on these investment alternatives is a critical step in our simulation algorithm. We assume that DC plan investors hold corporate stocks through mutual funds that invest in portfolios of large capitalization U.S. stocks. We do not address the possibility of poorly diversified portfolios or holdings of company stock, which are discussed in Munnell and Sunden (2004) and Poterba (2003). We assume that the distribution of returns on each of these asset classes is given by Ibbotson Associates' (2004) empirical distribution of returns during the 1926 to 2003 period. The average annual arithmetic real return on large capitalization U.S. equities during this period was 9.2 percent, and the annual standard 
deviation of the real return was 20.5 percent. Long-term U.S. government bonds had a real return of 2.8 percent, on average, over this period, and a standard deviation of 10.5 percent.

We assume that TIPS offer a certain real return of 2 percent per year, approximately the current TIPS yield. Index bonds deliver a net-of-inflation certain return only if the investor holds the bonds to maturity, and selling the bonds before maturity exposes the investors to asset price risk. We nevertheless treat these bonds as riskless long-term investment vehicles. When we draw returns from the stock and bond return distributions for a given "year" in our simulations, we draw returns for the same year from both distributions. This preserves the historical contemporary correlation structure between stock and bond returns.

Campbell (2001) and others argue that the period covered by our data sample was particularly favorable for equity markets and caution against extrapolating these returns to the future. To allow for such a possibility, we perform some simulations in which all equity returns are reduced by 300 basis points relative to their level in the actual historical distribution. These simulations indicate the sensitivity of our findings to the future pattern of equity returns.

Each time we simulate a DC plan balance at age 63, we draw a sequence of 35 real stock and bond returns from the empirical return distribution. The draws are done with replacement and we assume that there is no serial correlation in returns. We then use this return sequence to calculate the real value of each individual's DC plan balance at age 63 under the different asset allocation strategies. For each of the 1,400 workers in our sample, we simulate the DC balance at age 6350,000 times, thereby obtaining a distribution of wealth values at retirement. We present information on various percentiles and other summary measures of this distribution, and use the distribution to compute the expected utility of retirement wealth. We consider our full sample as well as subsamples defined by education levels.

We simulate seven different asset allocation strategies for each individual's DC account. The first three involve investing in only one asset: (i) TIPS; (ii) long-term government bonds, and (iii) corporate stock. Portfolio (iv) is an age-invariant 50-50 mix of stocks and TIPS, while portfolio (v) is a 50-50 mix of stocks and nominal government bonds. Portfolios (vi) and (vii) are lifecycle portfolios that 
combine stocks and TIPS, and stocks and nominal bonds. Marquez (2005) reports that Hewitt Associates estimates that 38 percent of all $401(\mathrm{k})$ plans offer lifecycle funds. The lifecycle funds offered at different fund families follow different age-phased asset allocation rules. PRVW (2005a) describe these funds in detail and report summary information on the investment patterns of several large lifecycle funds. We assign age-specific equity exposure rates equal to the average age-specific allocations in the set of lifecycle funds studied in PRVW (2005a).

We assume that DC plan returns equal the pretax returns on the various asset classes we consider, less an expense charge for investment management. Based on the expense ratio tabulations in PRVW (2005a), we assume a 74 basis point cost on investing in the lifecycle products. We assume a 32 basis point expense ratio on equity mutual funds, the weighted mean expense ratio on S\&P 500 index funds reported in Hortaçsu and Syverson (2004), and use the same expense ratio for government bond funds. We assume a 40 basis expense ratio for funds invested in TIPS.

\subsection{Summarizing the Distribution of DC Retirement Balances}

Our simulations yield a distribution of $\mathrm{W}_{\mathrm{i}}(63)$ for each individual for various asset allocation strategies. Comparing the distributions of retirement assets under various strategies indicates how these strategies affect retirement resources. The distribution of outcomes is of substantial interest, but it does not capture the individual's valuation of different levels of retirement resources. Since there is more dispersion with some investment strategies than with others, we need a metric for comparing a distribution with a lower mean but less dispersion with one with a higher mean and greater dispersion. We use a utility-of-terminal wealth approach, assuming that individuals have preferences over wealth at retirement that can be described by a constant relative risk aversion (CRRA) utility function

$$
U(W)=\frac{W^{1-\alpha}}{1-\alpha}
$$

where $\alpha$ is the individual's coefficient of relative risk aversion. Since individuals have wealth both in retirement plans and in other accounts when they reach retirement, we modify (2) accordingly: 


$$
U\left(W_{D C}, W_{n o n-D C}\right)=\frac{\left(W_{D C}+W_{n o n-D C}\right)^{1-\alpha}}{1-\alpha}
$$

The effect of DC wealth on an individual's utility depends on the individual's other wealth holdings. In our calculations we use all of the households's assets when we define $\mathrm{W}_{\text {non-DC, }}$, even though the DC plan balance is generated by only the husband's earnings.

For a given individual, each return history, denoted by h, generates a DC plan balance at age 63, $\mathrm{W}_{\mathrm{DC}, \mathrm{h}}$, and a corresponding utility level, $U_{h}$, where

$$
U_{h}=\frac{\left(W_{D C, h}+W_{n o n-D C(k)}\right)^{1-\alpha}}{1-\alpha}
$$

We evaluate the expected utility of each portfolio strategy by the probability-weighted average of the utility outcomes associated with that strategy. These utility levels can be compared directly for a given degree of risk tolerance. They can also be translated into certainty equivalent wealth levels $(Z)$ by asking what certain wealth level would provide utility equal to the expected utility of the retirement wealth distribution. The certainty equivalent of an all-equity portfolio, for example, denoted by the subscript SP500, is given by:

$$
Z_{S P 500}=\left[E U_{S P 500}(1-\alpha)\right]^{\frac{1}{1-\alpha}}-W_{n o n-D C}
$$

When individual DC participants have wealth outside a DC plan, the certainty equivalent of the DC wealth is the amount of DC wealth that is needed, in addition to the other wealth, to achieve a given utility level. We treat non-DC wealth as nonstochastic and use the value that each household reports in the HRS in all replications of our simulation analysis. We use the same procedure to compute the certainty-equivalent value of DB plan accumulations. Future work would benefit from allowing correlation between the value of DC plan assets at retirement and the value of other household wealth.

\section{Retirement Wealth Accumulation in DB Plans}

For each HRS respondent who is covered by a DB plan, there is a detailed summary of the plan in a supplementary file of Summary Plan Documents (SPDs). Plan provisions have also been codified in a 
Pension Estimation Program (PEP) that makes it possible to estimate the prospective DB pension payouts for each HRS respondent in a DB plan. Because the key inputs to the program are earnings records, this calculator can also be used to compute the DB plan accrual for individuals who are not actually covered by a DB plan. The PEP includes coding for the pension SPDs that the HRS collected from employers in 1993 and 1999, for plan years 1992 and 1998 respectively. The PEP is the source of the DB plan accumulations reported in Table 4 .

We use the PEP to estimate the counterfactual expected present discounted value of DB pension wealth for all sample participants assuming that they are assigned to a randomly selected DB plan for each of their jobs. The PEP takes as input an earnings history, a retirement or termination date, and a particular pension plan in the sample, and it generates a stream of retirement income payouts. With information on mortality rates and discount factors, these payouts can be used to estimate the expected present discounted value of future DB payouts, which is the measure of accrued DB wealth. The PEP can be used to estimate a given individual's DB pension wealth under different DB plans, thereby illustrating the risk associated with uncertainty of what DB plan a firm in the DB sector will offer, and it can be used to evaluate the payouts under a given DB plan for individuals with different earnings histories, thereby indicating the earnings risk associated with a particular plan. Individuals who prepare for retirement in DB plans face both plan risk and earnings risk.

To analyze DB accruals for a given individual, we need to separate the individual's earnings history into employment spells at various employers. The data requirements for such a separation are greater than those associated with measuring the stream of potential contributions to a DC plan, where we assumed that all earnings contributed to DC plan accumulation. We also need to select a sample of DB that we will consider in matching workers to plans. We consider each of these data issues in turn.

\subsection{Construction of Job Histories for HRS Respondents}

We construct job histories for each HRS respondent based on both his earnings history between ages 28 and 63 and his responses to various HRS questions about job tenure. The survey includes questions about the number of years the respondent has worked at his current or longest-tenure job. 
Unfortunately, we found that many responses were inconsistent across HRS waves, and that the resulting job histories matched poorly with reported earnings histories. We therefore chose not to rely exclusively on the self-reported job tenure information, but instead combined information from these questions with data from earnings histories. We infer the beginning and the end of a job from the HRS earnings history by assuming that years without earnings reflect job interruptions. Furthermore, in keeping with the assumptions used above in the top coding corrections, observations with less than $\$ 2500$ in real (year 2000) earnings are assumed to reflect part-year or part-time work and are therefore defined as a work interruption. This assumption may cause us to underestimate the length of some jobs that involved layoff or temporarily reduced workloads. Finally, given the typical characteristics of DB plans in our sample, we assume that a job did not generate any DB pension benefits unless it lasted for at least five years. Thus a given year of earnings yields a DB benefit accrual only if it occurs between ages 28 and 63, is greater than $\$ 2500$ in real dollars, and is part of a string of at least five consecutive years of earnings above this threshold. We assume that no one in our sample has more than three DB-eligible jobs during their work career, since very few individuals report DB pension benefits from more than three jobs.

Tables 6 and 7 present information on the job histories that we create using the algorithm described above. Table 6 shows the number of individuals, divided by educational attainment, who are assigned zero, one, two, and three jobs, respectively. Among the 1400 individuals in our sample, 77.2 percent (1081) are assigned a single DB-eligible job during their lifetimes, while 18.4 percent are assigned to two such jobs. The remaining 3.4 percent of the sample is divided equally between those who have no job that lasts more than five years and those who have three jobs. The distribution of number of jobs is similar for workers with different levels of educational attainment.

Table 7 reports the distribution of job lengths. Our unit of observation is a job, not an individual, so when we report that the median job for a person with less than a high school education lasted 25 years, this is the median of the $286 * 1+65 * 2+9 * 3=443$ jobs that we observe for individuals in this education category, not the median for the $286+65+9=360$ individuals in this education category. Table 7 shows that most jobs are long-lasting. The $25^{\text {th }}$ percentile value for job length for all three education sub- 
samples is either 11 or 12 years, and the median job length is between 24 and 27 years. One quarter of all jobs last at least 33 years. These data indicate that a substantial subgroup of workers reaching retirement age in the 1990s had long-term jobs that are consistent with substantial DB plan accumulation. Another significant subgroup of workers, however, worked at several different jobs, and would have been unlikely to accumulate substantial DB pension wealth. Our simulation results indicate how important the risk of short jobs is for the accumulation of DB plan resources.

\subsection{Selecting a Sample of DB Plans}

We selected the 25 largest public-sector and 25 largest private-sector DB plans, ranked by number of HRS participants covered by the plan, as our universe of DB plans. We used the 1998 HRS pension sample because it has better coverage than earlier years. All of the plans are associated with large employers. In most cases the private sector employers are large national firms. The public sector pension plans are often connected with state-managed programs for public sector employees, so in some cases employees at many different localities may be covered by the same state-wide pension plan.

While confidentiality issues preclude reporting of individual DB plan attributes, the plans in our sample display many diverse provisions. This diversity suggests the limitation of any analysis of DB and DC plan risk that is based on only a stylized example of a DB plan, as in some previous analyses of DB vs. DC plan risk. In the private sector, there are some similarities across plans, but important differences. Virtually all of the plans use five-year cliff vesting, which is consistent with our focus on five year jobs as the shortest jobs that will generate DB benefit accruals. Most plans also use age 65 as a normal retirement age. There is substantial divergence, however, in the early retirement provisions of different plans, and in the earnings measure that is used to determine benefits. Social Security integration provisions also vary, with eleven of the 25 private-sector plans offering no integration and the remaining 14 choosing a variety of integration strategies.

Among public sector plans, there are also some margins of similarity, and others of divergence, but the patterns are different from those for private-sector plans. There is more variation in both the vesting rules for the public sector plans and in the normal retirement ages embodied in these plans than in 
the comparable private-sector plans. The public sector plans typically provide benefits based on a measure of highest average earnings over a several-year interval. They are also homogenous with respect to Social Security integration. Only two of the 25 public sector plans in our sample are integrated with Social Security. There is substantial heterogeneity among public sector plans with regard to early retirement provisions, as there is with private sector plans.

Our summary of the provisions of the DB plans focuses on the standard provisions of each DB plan, not on special "window" provisions that are sometimes used to encourage early retirement or retirement more generally. The periodic introduction of such provisions adds further variability to the prospective benefit accruals in the DB sector, and can create incentives for early retirement and other changes in participant behavior.

\subsection{Calculating the PDV of DB Wealth}

Our simulations assign an individual with a given earnings and job history to a particular DB plan, and calculate the resulting present discounted value of DB pension wealth. We assume a five percent nominal discount rate, a two percent real discount rate, and a real wage growth rate of one percent per year. For plans that are integrated with Social Security, we assume the historical growth rate of Social Security benefits for past years and a zero real benefit growth rate prospectively. We specify that benefits are taken in the form of a 50 percent joint-and-survivor annuity, given that the sample comprises married men, and we use the PEP to estimate the presented discount value of benefits assuming a retirement age of 63. Our calculations assume that DB plan participants live until at least age 63. This means we have suppressed one of the risks of DB plan participation, namely the risk of early death. While a DC plan participant can bequeath assets in this scenario, a DB plan participant loses the value of his accumulated retirement wealth if he dies before the benefits begin. More generally, DB plan beneficiaries, like any annuity recipients, receive greater payouts if they live longer.

To transform the distribution of accumulated DB wealth under different DB plans into an expected present discounted value of DB wealth, we average the outcomes of various simulation runs. We construct separate averages for public sector and private sector plans, since the public sector plans 
tend to be more generous than their private sector counterparts. Our algorithm assumes that each time an individual takes a job at a firm with a DB plan, the plan is drawn randomly from the 25 public sector, or 25 private sector, plans in our sample. We repeat the randomization for each job in the individual's career, so for an individual with three jobs, there are $25^{3}$ possible combinations of public sector DB plans and the same number of possible private sector DB plan combinations. Our algorithm does not allow for migration between the public and the private sector; an individual who works in one sector is restricted to remain in that sector throughout his working life. The randomization over DB plans is different from that for DC plans, where we assumed that a given DC contribution percentage would apply throughout the participant's lifetime.

We use the distribution of DB wealth values to compute certainty equivalent measures of DB wealth, just as we did for DC wealth outcomes above. The utility associated with a given DB plan outcome is

$$
U\left(W_{D B}, W_{n o n-D B}\right)=\frac{\left(W_{D B}+W_{n o n-D B}\right)^{1-\alpha}}{1-\alpha} .
$$

This expression can be solved for the certainty equivalent of a given distribution of DB wealth outcomes. The same issues of measuring non-pension wealth that arose in the DC plan setting also arise with regard to DB wealth measurement. As with DC plans, we assume that non-pension wealth is nonstochastic.

\section{Comparison of DC and DB Wealth Distributions}

We present our findings by first reporting on simulated DC plan balances at age 63, and then showing analogous measures of DB wealth at the same age. Because we consider a number of different asset allocation strategies and asset return assumptions in our analysis of DC plans, we devote more discussion to the DC than the DB findings.

\subsection{Plan Balances at Retirement}

Table 8 shows the distribution of DC plan balances in thousands of year 2000 dollars averaged across the 1400 individuals in our sample. The simulations in the left panel use the historical distribution of returns, while those in the right panel use modified returns in which the average yield on equities is 300 
basis points below its historical average. Individuals are stratified by education group within each panel. The table reports the mean wealth at retirement for each strategy, as well as four points in the distribution of returns. Since we are interested in the dispersion of DC wealth accumulation for individuals of different types, as well as the effect of different asset allocation strategies on wealth accumulation, most of the discussion below focuses on a single education group, individuals with a high school degree but not a college degree. Relative rankings of different strategies are similar for other education groups.

The first rows in Table 8 show the wealth at retirement associated with holding only TIPS in the DC account. The investment returns from this strategy are riskless, but the fact that the contribution rate is randomly drawn for individual still generates a distribution of retirement wealth outcomes. The mean result of the TIPS simulation for individuals with high school and/or some college, $\$ 177,000$, provides a useful benchmark for the discussion that follows. The risk associated with DC plan contribution rates yields a first percentile outcome of $\$ 39,100$, a tenth percentile outcome of $\$ 58,600$ and a ninetieth percentile outcome of $\$ 325,500$ for this group.

The second panel shows that holding only government bonds leads to a higher average DC balance at retirement, $\$ 213,400$, than holding only TIPS. The average DC plan balance at 63 is over twenty percent greater than the value with TIPS, but the median value of $\$ 176,200$ is less than ten percent above the TIPS outcome. This reflects a higher average real return on nominal government bonds than on TIPS in our simulations. Moreover, there is a greater spread of outcomes with nominal government bonds than with inflation indexed bonds. The 1 st percentile outcome is $\$ 26,100$ with nominal bonds, compared with $\$ 39,100$ for TIPS, and the $90^{\text {th }}$ percentile outcome is $\$ 410,900$, compared with $\$ 325,500$. The variation in outcomes from holding TIPS is due only to variation in contribution rates, while the variation from holding nominal government bonds includes variation from different real return histories as well.

When the DC plan balance is invested in corporate stock, the average retirement balance is much higher than that with either TIPS or nominal government bonds: $\$ 918,900$. This value is roughly four times greater than the outcome with nominal government bonds. Because the mean return on stocks is so 
much higher than that on either nominal or inflation-indexed bonds, even the outcomes in relatively low quantiles are often above the mean outcomes with bonds. The median retirement wealth value with the all-stocks portfolio exceeds the $90^{\text {th }}$ percentile outcome with a nominal government bond portfolio. At lower quantiles, however, the outcome with the all-stocks portfolio allocation falls below the value for the corresponding quantile for the TIPS and nominal bonds allocations.

The next two rows in each panel consider the two "50-50" portfolios constructed using either stocks and TIPS or stocks and nominal government bonds. At the mean and across most quantiles of the distribution, these investment strategies result in significantly lower levels of retirement wealth than stocks alone. The mean outcome of a 100 percent portfolio of stocks is 2.3 times as large as the mean outcome of a mix of 50 percent TIPS and 50 percent stocks, and 2.1 times as large as the mean outcome of a 50-50 stock/government bond mix. Even at the $10^{\text {th }}$ percentile, a portfolio of 100 percent stocks outperforms a 50-50 stock/TIPS portfolio by 20 percent. The mixed portfolio yields a larger DC wealth accumulation than the all-stock portfolio only at the lowest quantiles of the distribution.

The last two horizontal panels of Table 8 consider portfolios that are allocated to lifecycle funds that are a mix of either stocks and TIPS or stocks and government bonds. Even though the expense ratios of these funds are higher than those we assumed when assets were held only in stocks or bonds, the lifecycle funds yield slightly higher average values of DC wealth accumulation than their 50-50 counterparts. Because their expenses are higher, however, the lower quantiles of the distributions for these funds are lower than the corresponding quantiles for the 50-50 allocation rules. The entries in the bottom decile, for example, of the stocks-TIPS lifecycle fund are lower than those in the bottom decile of the 50-50 stocks/TIPS strategy. These findings underscore the importance of considering expenses in analyzing the risk of DC plan wealth accumulation, and especially in evaluating the outcomes with weak asset market returns.

The assumption that the equity return is drawn from its historical distribution affects the level of retirement wealth under most of the strategies that we consider, and it also affects the differences across strategies. The fourth, fifth, and sixth columns in Table 8 present results assuming that equity returns are 
reduced by 300 basis points. The all-stock strategy is the one that is most affected by this change. The average wealth at retirement for this strategy falls from $\$ 918,900$ to $\$ 452,300$. The tenth percentile wealth value drops from $\$ 127,000$ to $\$ 66,300$, and the first percentile value drops from $\$ 39,300$ to $\$ 21,200$. With the all-stock portfolio, and to lesser degree with other portfolios that have some equity exposure, there is a small chance of a very poor outcome. This outcome becomes poorer when the average equity return is reduced. The average retirement wealth values for the various heuristic and empirical lifecycle funds decline when we reduce the value of the mean equity return, since these funds have substantial equity exposure.

Table 9 repeats the exercise in Table 8 but assumes that annual contributions as a share of salary are the same for all participants in DC plans. We set all these contribution rates to the sample average for HRS males who participate in a DC plan. This provides a way of understanding how much of the dispersion in DC plan outcomes is due to "plan risk" and how much is due to asset market risk. The mean of any given investment strategy in Table 9 is therefore the same as in Table 8, except for small differences that are below the numerical precision of our simulation algorithm. These differences are generally smaller than $\$ 100$, while retirement wealth in our analysis is several hundred thousand dollars. The 100 percent TIPS strategy in Table 9 is riskless, however, while that in Table 8 is risky because of uncertainty about DC plan parameters. When we compare outcomes within education-asset allocation strategy cells in Tables 8 and 9, the lower percentile outcomes are worse in Table 8 than in Table 9 due to the contribution risk while the higher percentile outcomes are better. The randomness in contribution patterns adds variance to the distribution of DC plan balances at retirement.

To summarize the value of different wealth distributions for individuals who are risk-averse, we compute the expected utility associated with DC wealth distributions underlying Table 8 and find the wealth value that generates the same utility - the certainty equivalent wealth value. Table 10 shows the certainty equivalent values associated with the distributions of DC plan values in Table 8 . The calculations in this table assume that in addition to DC plan wealth, each individual also has whatever household financial wealth the HRS reports outside retirement accounts, and that the individual has Social 
Security wealth and any other annuity wealth reported on the survey. For households with negative values of other wealth, we set other wealth to zero, thereby avoiding the possibility that certainty equivalent might be undefined. The entries reported in Table 10 are based on a smaller number of simulation runs than the corresponding entries in Tables 8 and 9 .

The values in the first horizontal panel in Table 10 are based on linear utility $(\alpha=0)$ and thus are the expected values of each investment choice. These results coincide with the average DC plan balance results in Table 8; a risk-neutral individual cares only about the expected value of his DC plan retirement balance. A risk neutral individual would find the all-stock strategy the most attractive investment rule, since it offers the highest average DC wealth regardless of the individual's education group and whether the average stock return is set to its historical average or reduced to 300 basis points below that average.

The next horizontal panel in Table 10 presents results for individuals whose utility of retirement wealth is logarithmic. This level of risk aversion reduces the certainty equivalent value of the all-stock portfolio strategy relative to other strategies, but all this strategy continues to generate the highest expected utility for all education groups even when the expected return on stocks is reduced by 300 basis points. Of the various mixed strategies and lifecycle approaches, the empirical lifecycle strategy with stocks and bonds generates the best outcomes when stock returns are drawn from the unadjusted empirical distribution, and the 50-50 stocks-bonds strategy generates the highest certainty equivalent value with reduced returns.

The third and fourth horizontal panels in Table 10 consider individuals whose relative risk aversion coefficients are two and four, respectively. Even at these higher levels of risk aversion, the allstock portfolio strategy dominates the other strategies in certainty equivalent terms, and this continues to be the case even when stock returns are reduced by 300 basis points. The table shows that among the mixed strategies, the 50-50 stocks-bonds strategy yields the highest expected utility for participants with constant relative risk aversion of two and above.

We do not report certainty equivalent calculations that correspond to the results in Table 9 using sample average DC plan parameters. The certainty equivalent values in these cases display the same 
patterns as in the cases with uncertainty about DC plan attributes, but they are generally higher than the values reported in Table 10. This is because the DC plan balances in the lower tail of the distribution, which corresponds to adverse outcomes with a low DC contribution rate and a poor set of asset returns, are higher, since the risk of a low DC plan contribution rate is eliminated.

All our certainty equivalent wealth calculations recognize that HRS households have Social Security benefits, which are nearly universal, and other non-retirement financial assets. If households have any other annuity income, which is rare, this is also included in the non-DC plan wealth. Nonretirement financial assets are modest except at the highest levels of the wealth distribution. The presence of these other assets, however, and in particular the recognition of Social Security wealth, raises the certainty equivalent of equity-based allocation rules relative to other investment strategies. The cost of holding equities from the standpoint of a risk-averse individual is the risk of a very low payout associated with very poor returns over many periods. When individuals have a fallback level of consumption assured by their Social Security benefits, they are effectively more willing to bear risk. PRVW (2005a) compare the certainty equivalent wealth values associated with different asset allocation strategies when individuals have no outside wealth and when they have other assets. In some cases the relative ranking of equity-based strategies and other strategies changes, depending on the assumption we make about other wealth holdings, because the presence of other assets provides a buffer against very low consumption levels corresponding to very low DC plan balances.

\subsection{DB Balances at Retirement and Certainty Equivalent Measures}

The same concepts described above can be applied to study wealth accumulation under DB plans. We consider two cases, corresponding to drawing the DB plan from the private and the public sector plan distributions. Table 11 shows the distribution of DB plan balances averaged across the 1400 individuals in our sample. The entries indicate the present discounted value of DB plan benefits from the perspective of an individual at age 63 . We again stratify individuals by education group within each panel. The table reports the mean wealth at retirement as well as four points in the distribution of returns. As in our 
discussion of DC plan balances, we focus primarily on the intermediate education group, the group with a high school degree but not a college degree.

The results in Table 11 suggest several conclusions about DB plan accumulation. First, they highlight the substantial differences between the benefit accruals for private-sector and public-sector plans. For the high school educated group, the mean value of DB plan accumulations at age 63 is $\$ 156,000$ for the sample of private sector plans, compared with $\$ 316,800$ for public sector plans. The proportional differences are larger for those in other education categories. Note that these results represent averages across individuals with various earnings histories, and that they average across various DB plans in each sector. Our ability to distinguish DB plan accumulations for public and private sector plans is an important insight that emerges from the detailed plan parameters codified in the PEP.

Second, the mean level of DB wealth accumulation in private sector plans is lower than the mean wealth accumulation in average DC plans, even when the asset allocation rule is conservative investments in riskless inflation-indexed bonds. For a high-school educated worker, the mean (median) value of the DB pension accrual at retirement is $\$ 156,000(\$ 150,600)$, compared with $\$ 177,000(\$ 167,400)$ for a TIPS-invested DC plan. If the DC plan is invested partly in corporate equities, so that the expected return is higher, then the disparity between the means in the DB and the DC plans is even greater. The upper end of the distribution of DC plan balances is greater than the upper tail of the DB plan accumulations for all of the asset allocation rules that we consider.

The comparison between private sector DC plans and public sector DB plans is more subtle. On average, public sector DB plans are more generous than private sector plans. The mean and median DB plan accruals in public sector plans exceed the mean and median for conservatively-invested DC plans. The median public sector DB plan accumulation, $\$ 326,800$ for an individual with a high school education, is nearly $85 \%$ greater than the median DC plan accrual for a comparable individual who invests only in taxable government bonds $(\$ 176,200)$ or TIPS $(\$ 167,400)$. The DB plan accruals are also slightly larger than those from working under a DC plan and pursuing an investment strategy of 50-50 stocks and TIPS, 
which yields a median of $\$ 321,000$. The DB plan accruals are slightly smaller than the accruals in a DC plan that is invested 50-50 in stocks and nominal bonds, which yields a median of $\$ 336,600$.

The comparison between public sector DB plans and private sector DC plans becomes more favorable for the former when average equity returns are reduced by 300 basis points relative to their historical average. Recall from Table 8 that the mean value of DC wealth accumulation for a high schooleducated individual is between $\$ 280,000$ and $\$ 310,000$ for all of the lifecycle and 50-50 strategies that we consider, while the DB accumulation averages $\$ 316,800$. The DB and DC values are much closer in this case then when the equity returns are drawn from the actual historical distribution. The mean DB plan accumulation is also substantially greater than the mean DC accumulation when the asset allocation strategy involves holding either TIPS or nominal long-term government bonds, although it falls short of the mean DC accumulation when the DC assets are fully invested in stocks even with reduced returns.

Table 12 reports the certainty equivalent wealth values corresponding to the distribution of DB plan accruals underlying Table 11. As in Table 10, we consider individuals in four different risk aversion categories. The reduction in the certainty equivalent of the DB plan distributions is modest as we increase the relative risk aversion coefficient for the individual pensioner. For private sector DB plans, raising this parameter from zero, which denotes risk neutrality, to four, which implies substantial risk aversion, translates into a ten percent decline in the certainty equivalent wealth of the private sector DB plan accrual for a high-school educated worker. The effects are more pronounced for college-educated workers, because while the mean accrual is significantly higher, there remains a significant probability of an interrupted work career that results in only modest benefit accruals. In the public sector, the decline in the certainty equivalent wealth is even more pronounced, reflecting a higher level of benefits in most cases, but a residual risk of some low-benefit outcomes.

\subsection{Comparing Certainty Equivalent Outcomes}

The certainty equivalent wealth calculations in Tables 10 and 12 provide key evidence that bears on the question underlying this paper: are DC plans riskier than DB plans? Our answer is of course conditioned on the many assumptions that underlie our calculations, but it suggests that for plausible 
parameter values, the certainty-equivalent value of retirement wealth accruals associated with working in a setting that provided only DC plans is substantially greater than the certainty equivalent value of working under a regime of private-sector DB plans. For a risk neutral individual, there are no scenarios under which drawing a DB plan randomly from the distribution of private sector plans leads to a certainty equivalent that is higher than that associated with drawing a DC plan from the plan population. A risk neutral individual, given the choice of selecting either a random private sector DB plan or a random DC plan, would choose the DC plan. For example, if the individual had high school and/or some college education, his certainty equivalent in a randomly-chosen private sector DB plan would be $\$ 156,000$. This is below the range of certainty equivalents of DC plans for this risk aversion and education category, which is from $\$ 177,000$ to $\$ 918,900$ depending on the asset allocation rule used to invest plan balances.

For individuals with risk aversion of 1,2 , or 4 , the result is similar, although for workers with high levels of education the DB plan accrual in a private sector DB plan may exceed the value of a DC plan with a TIPS-only asset allocation strategy. For example, an individual with some college education and a relative risk aversion coefficient of two has a private-sector DB certainty equivalent of $\$ 147,600$, compared with DC plan certainty equivalents between $\$ 159,100$ and $\$ 477,900$. An individual with a relative risk aversion coefficient of two and a college or postgraduate education has a certainty equivalent of $\$ 229,900$ from the private sector DB plan, which is less than any of the corresponding DC outcomes except the all-TIPS case which yields $\$ 226,700$.

For a risk neutral individual, there some scenarios under which a public sector DB plan generates a higher certainty equivalent of DB plan wealth than the certainty equivalent of a many DC plan/asset allocation combinations, but there is always at least one DC plan asset allocation rule that dominates even the public sector DB option. This is true regardless of our assumption about equity returns. For example, the highest certainty-equivalent wealth for a DB plan accumulation for a risk neutral individual is $\$ 544,700$ for an individual with a college or post-graduate degree in a public sector DB plan. This is greater than the $\$ 251,600(\$ 299,400)$ certainty equivalent wealth that the individual would have accrued in a DC plan invested entirely in TIPS (nominal bonds). It is also greater than the $\$ 384,700(\$ 421,900)$ 
that would accrue in a DC plan invested 50-50 in stocks and TIPS (nominal bonds) with a reduced return on equities. If the DC plan is invested fully in stocks, however, the certainty equivalent of the accrual at retirement exceeds that for a DB plan when stocks earn their historical returns $(\$ 1,182,500)$ or a 300 basis-point reduced return $(\$ 604,300)$. Similarly, a risk-averse individual with a high school degree and/or some college in a public sector DB plan would have a certainty equivalent of $\$ 316,800$ for the DB plan accruals, which exceeds the certainty equivalent for a DC plan accrual if the plan is invested in TIPS $(\$ 177,000)$ or government bonds $(\$ 213,400)$. The DB plan accrual does not exceed the value of the DC plan accruals with other asset allocation strategies.

For a risk-averse individual, the relative performance of DC versus public DB plans is dependent on the equity return assumptions for the DC plan, the level of education for the participant, and the participant's level of risk aversion. For an individual with a high school education and relative risk aversion of one or two, if equity returns follow their historical empirical distribution, the certainty equivalent outcomes of all of the DC plan accruals that involve some equity exposure exceeds the certainty equivalent of the public sector DB plan. For example, when the coefficient of relative risk aversion is unity, an individual with this level of education has a public sector DB certainty equivalent of $\$ 307,400$, a DC certainty equivalent of $\$ 194,300$ for an all-bonds investment strategy, and a DC certainty equivalent of at least $\$ 344,300$ for investment strategies that include some equities. A similar pattern holds for when the relative risk aversion coefficient is two, but the pattern reverses when the risk aversion coefficient is four. At four, the individual achieves a higher certainty equivalent value $(\$ 264,700)$ with a public sector DB plan than with any DC plan except one invested completely in stocks. For individuals in the highest education category and risk aversion of one, two, or four, the public sector DB certainty equivalent is larger than the certainty equivalent from any DC strategy except all stocks.

If equity returns are 300 basis points lower than their historical empirical distribution, sufficiently risk-averse individuals achieve higher certainty equivalents in public sector DB plans than in DC plans. This turns out to be especially the case for higher education individuals, who may have more stable earnings histories that generate less DB plan risk. For example, for an individual with high school and/or 
some college and a relative risk aversion coefficient of two, the public sector DB certainty equivalent of $\$ 264,700$ is greater than that of most of the DC investment strategies, but is smaller than the $100 \%$ stocks DC certainty equivalent of $\$ 273,900$. However, if risk aversion is high enough under the reduced equity return scenario, the public sector DB certainty equivalent exceeds that from DC plans. For those with a high school degree and/or some college, this happens at a coefficient of relative risk aversion of four. A public sector DB generates a certainty equivalent of $\$ 264,700$, compared with $\$ 202,300$ for the most attractive DC plan and allocation strategy. For the college or post-graduate group, the dominance of the public sector DB plans can occur with relative risk aversion coefficients as low as one, where the public sector DB generates a certainty equivalent of $\$ 524,100$ compared to the best DC certainty equivalent of $\$ 467,600$. While it is difficult to distill a single pattern from the results presented in Tables 10 and 12 , it is clear that the calculations do not support the simple conclusion that DB plans are less risky than DC plans, and that the certainty equivalent value of these plans is greater than that for DC plans.

\section{$\underline{\text { 6. Conclusions }}$}

This paper presents new evidence on the expected value of retirement wealth accruals under defined benefit (DB) and defined contribution (DC) retirement plans. We use actual retirement plans that cover respondents in the Health and Retirement Study, and compute prospective wealth accruals using the actual earnings and employment history of these respondents. We can therefore compare not only the average value of retirement wealth, but also its dispersion, recognizing uncertainty about: (i) which plan the individual's employer will offer; (ii) the individual's employment history and earnings trajectory; and (iii) the returns earned by investments held in DC plans. We compare, in a similar framework, the asset market risk facing participants in DC plans and the employment history risk facing DB plan participants. The asset market risk for DC plan participants is sensitive to the asset allocation choices they make, while the employment history risk for DB participants is sensitive to their risk of job change. We extend

previous studies of DB and DC plan risk, notably those by Samwick and Skinner (2004) and Schrager (2006), by utilizing rich information on the structure of lifetime earnings histories. 
Our findings on retirement wealth accumulations highlight important heterogeneity across different plans. We distinguish, for example, DB plans in the public sector from those in the private sector. Because the former are substantially more generous, on average, than the latter, workers covered by public sector DB plans accumulate substantially greater retirement resources than workers in the private sector DB system. Similarly, there is substantial heterogeneity across private sector DC plans, with corresponding differences in retirement resources for workers.

Our estimates of the average level of wealth accumulated in DC and DB plans depend on how the DC plan participant allocates assets across different investment options and on whether the DB plan participant is in the public or the private sector. Private sector DB plans are almost always dominated by DC plans, at least under the parameterizations we study. The comparison between public sector DB plans and representative DC plans, mostly private sector plans, is particularly sensitive to assumptions. If equity returns follow their historical empirical distribution, an individual in a DC plan who makes substantial equity investments will usually achieve a higher certainty equivalent outcome in a DC plan than in a public sector DB plan. If equity returns are 300 basis points lower than their historical empirical distribution, individuals with relatively low levels of risk aversion and/or high risk of job turnover will still achieve higher certainty equivalents with a carefully chosen DC plan. However, sufficiently riskaverse individuals will attain a higher level of expected utility under a public sector DB plan than under a DC plan. This turns out to be especially the case for individuals in the highest education categories.

Our findings on the certainty-equivalent wealth associated with different pension arrangements are sensitive to our assumptions about relative risk aversion and to the amount of non-retirement wealth available to individuals. There are unresolved conceptual issues associated with the measurement of such wealth. Consider the case of housing wealth, which we have excluded from non-retirement wealth. If such wealth is a source of retirement income support that should be included in our measure of nonretirement wealth, then our results imply too much aversion to highly disperse DB and DC plan outcomes and they understate the certainty equivalence values. Alternatively, if we recognize the stochastic nature 
of non-retirement wealth, the covariance of pension wealth and other wealth will result in a decline in the certainty equivalent values we compute.

Our findings represent a first step toward comparing the relative risks of DB and DC plans using actual earnings histories rather than parametric forms for the earnings and job change process. A natural next step in our research involves comparing the distribution of actual DB and DC wealth in the HRS with the distributions that emerge from our simulations. Since we are using the actual earnings histories of HRS respondents, if respondents are matched randomly to pension plans, as we assume, and if the pension plan environment has been stationary through the working life of the HRS respondents, which it has not been, then the observed distribution should be similar to the one generated by our simulations. Comparing these distributions and explaining their differences is a direction for further work.

Even without the input from such a distributional comparison, we are aware that there are many ways in which our algorithm for computing retirement wealth could be extended and improved. For example, we do not allow for lump sum distributions from DC plans, even though Engelhardt (2002) and Poterba, Venti, and Wise (1998) suggest that these distributions exert a potentially important drag on retirement wealth accumulation. We have not allowed for differences in asset allocation patterns as a function of individual characteristics, such as education, even though past research such as Ameriks and Zeldes (2004) suggests that there are such differences. We have not considered the role of uncertain inflation and its impact on the real retirement wealth of DB and DC plan participants. We do not allow earnings trajectories or the length of the work life to respond to the structure of pension arrangements, even though Friedberg and Webb (2005) suggest that DC plan participants have longer work lives than their DB counterparts, at least potentially because of the retirement incentives that are incorporated in many DB plans. We do not consider how pension arrangements may affect the non-retirement investment decisions of pension participants. Friedberg and Webb (2006) suggest that DC participants are more likely to hold corporate equities outside their pension account than are comparable households without DC coverage. Weisbenner (2002) also suggests that there may be spill-over effects from the pension portfolio to non-pension holdings. This may be consistent with a "learning about equities" model, rather 
than a model of risk substitution which might be a more standard approach to this question. Addressing any of these issues will add greater realism to our simulation algorithm.

Finally, our analysis has treated the individual's wage profile as unaffected by the presence or absence of various pension arrangements, and we have not considered the question of employer cost for various retirement programs. We have treated the worker's wage profile as given and randomly assigned a retirement program to the worker. Standard models of wage determination in the presence of employerprovided benefits, however, suggest that all else equal, workers with more generous pension benefits should receive lower wages. This would suggest that when we draw a DC plan with substantial employer contributions or a DB plan with generous provisions, we should adjust the individual's earnings trajectory to reflect these generous payouts. In particular, one could hold the present value of the employer's pension cost (or total compensation cost) equal between DB and DC plans and compare outcomes under that restriction. Allowing for potential earnings responses would raise a complex set of issues about household wealth accumulation outside the pension account, and how it is affected by the lifetime pattern of wage income. The results from such an analysis would be sensitive to assumptions about the extent to which individuals make forward-looking decisions, and the value they place on future DB benefits. The literature on how wages adjust to retirement plan provisions has long struggled with difficult issues of identification, since the benefit mix is endogenous and not all worker attributes can be observed. Further insights on this issue, however, are essential for understanding the long-run effect of the ongoing transition from DB to DC pension plans. 


\section{$\underline{\text { References }}$}

Ameriks, John anda Stephen Zeldes, 2004, "Do Household Portfolio Shares Vary with Age?," Columbia University Graduate School of Business.

Balcer, Yves, and Izzet Sahin, 1979, "A Study of Private Pensions in Ontario," Institute for Research on Poverty Discussion Paper, University of Wisconsin - Madison.

Bodie, Zvi, Alan Marcus, and Robert Merton, 1988, "Defined Benefit vs. Defined Contribution Pension Plans: What are the Real Trade-Offs?," in Z. Bodie, J. Shoven, and D. Wise, eds., Pensions in the U.S. Economy (Chicago: University of Chicago Press).

Buessing, Marric and Mauricio Soto, 2006, "The State of Private Pensions: Current 5500 Data," Issue Brief 42, Center for Retirement Research, Boston College.

Campbell, John Y., 2001, Forecasting Equity Returns in the $21^{\text {st }}$ Century, mimeo, Harvard University.

Cunningham, Chris, Gary Engelhardt, and Anil Kumar, 2006, "Measuring Pension Wealth," mimeo, Maxwell School Syracuse University.

Engelhardt, Gary, 2002, "Pre-Retirement Lump Sum Pension Distributions and Retirement Income Security: Evidence from the Health and Retirement Study," National Tax Journal 55, 665-686.

Friedberg, Leora and Michael Owyang, 2005, "Explaining the Evolution of Pension Structure and Job Tenure," Federal Reserve Bank of St. Louis Working Paper 2002-022D.

Friedberg, Leora and Anthony Webb, 2005, "Retirement and the Evolution of Pension Structure," Journal of Human Resources 40, 281-308.

Friedberg, Leora and Anthony Webb, 2006, "The Impact of Pensions on Non-Pension Investment Choices," mimeo, University of Virginia.

Gustman, Alan L., Olivia S. Mitchell, Andrew A. Samwick, and Thomas L. Steinmeier, 2000, "Evaluating Pension Entitlements," in Olivia S. Mitchell, P. Brett Hammond, and Anna M. Rappaport, eds., Forecasting Retirement Needs and Retirement Wealth (Philadelphia: University of Pennsylvania Press), 309-326.

Gustman, Alan and Thomas Steinmeier, 2004, "What People Don't Know About Their Pensions and Social Security," in William Gale, John Shoven, and Mark Warshawsky, eds., Private Pensions and Public Policies (Washington: Brookings Institution), 57-125.

Hortaçsu, Ali and Chad Syverson, 2004, "Search Costs, Product Differentiation, and Welfare Effects of Entry: A Case Study of S\&P 500 Index Funds," Quarterly Journal of Economics 119(4), 403-456.

Ibbotson Associates, 2004, Stocks, Bonds, Bills, and Inflation: 2003 Yearbook: Market Results for 19262003. (Chicago: Ibbotson Associates).

Marquez, Jessica, 2005, "Lifecycle Funds Can Help Companies Mitigate Risk and Boost Employee Savings," Workforce Management, April, 65-67.

Moore, James F. and Olivia S. Mitchell, 2000, "Projected Retirement Wealth and Savings Adequacy in the Health and Retirement Study," in O. S. Mitchell, B. Hammond, and A. Rappaport, eds., Forecasting Retirement Needs and Retirement Wealth (Philadelphia: University of Pennsylvania Press), 68-94.

Munnell, Alicia, Francesca Golub-Sass, Mauricio Soto, and Francis Vitagliano, 2006, "Why Are Healthy Employers Freezing Their Pensions?," Issue Brief 44, Boston College Center for Retirement Research.

Munnell, Alicia and Annika Sunden, 2004, Coming Up Short: The Challenge of 401(k) Plans (Washington: Brookings Institution).

Peticolas, Bob and Helena Stolyarova, 2003, "Pension Estimation Program Users Guide," Working Paper, University of Michigan Institute for Social Research.

Poterba, James, 2003, "Employer Stock and 401(k) Plans," American Economic Review 93 (May), 398404. 
Poterba, James, Joshua Rauh, Steven Venti, and David Wise, 2005a, "Lifecycle Asset Allocation Strategies and the Distribution of 401(k) Retirement Wealth." NBER Working Paper 11974. (Forthcoming in D. Wise, ed., Developments in the Economics of Aging).

Poterba, James, Joshua Rauh, Steven Venti and David Wise, 2005b, "Utility Evaluation of Risk in Retirement Savings Accounts," in David Wise (ed), Analyses in the Economics of Aging, Volume 10, University of Chicago Press.

Poterba, James, Steven Venti, and David Wise, 1998, "Lump-Sum Distributions from Retirement Saving Plans: Receipt and Utilization," in D. Wise, ed., Inquiries in the Economics of Aging (Chicago: University of Chicago Press), 85-105.

Rohwedder, Susann, 2003, "Measuring Pension Wealth in the HRS: Employer and Self-Reports," mimeo, RAND Corporation.

Samwick, Andrew and Jonathan Skinner, 2004, "How Will 401(k) Plans Affect Retirement Income?" American Economic Review 94, 329-343.

Scholz, J. Karl, Ananth Seshadri, and Surachrai Khitatrakun, 2006, “Are Americans Saving 'Optimally' for Retirement?," Journal of Political Economy 114, 607-643.

Schrager, Allison, 2006, "A Life-Cycle Analysis of the Decline of Defined Benefit Plans and Job Tenure," Columbia University Working Paper.

Shiller, Robert, 2005, "The Life Cycle Personal Accounts Proposal for Social Security: A Review," NBER Working Paper 11300.

U.S. Census Bureau, 2006, "Number and Membership of State and Local Government EmployeeRetirement Systems by State," http://www.census.gov/govs/retire/2004ret05a.html.

Venti, Steven, and David Wise, 2001, "Aging and Housing Equity: Another Look," in D. Wise, ed., Analyses in the Economics of Aging (Chicago: University of Chicago Press).

Weisbenner, Scott, 2002, "Do Pension Plans with Participant Investment Choice Teach Households to Hold More Equity?," Journal of Pension Economics and Finance 3, 223-248. 
Table 1: Thousands of Workers in Private Sector DB and DC Plans, 1990-2003

$\begin{array}{rrrr} & \text { DB Only } & \text { DC Only } & \text { Both } \\ 1990 & 9,611 & 11,541 & 13,659 \\ 1991 & 9,326 & 12,124 & 14,571 \\ 1992 & 8,456 & 13,154 & 14,865 \\ 1993 & 7,895 & 14,199 & 15,220 \\ 1994 & 8,189 & 15,064 & 14,464 \\ 1995 & 7,555 & 17,542 & 14,445 \\ 1996 & 7,436 & 18,897 & 14,533 \\ 1997 & 7,266 & 22,776 & 14,559 \\ 1998 & 7,783 & 24,091 & 14,448 \\ 1999 & 7,123 & 24,902 & 14,282 \\ 2000 & 6,259 & 27,792 & 13,944 \\ 2001 & 6,200 & 29,112 & 13,649 \\ 2002 & 6,696 & 29,338 & 14,276 \\ 2003 & 6,579 & 30,061 & 14,943\end{array}$

Source: Buessing and Soto (2006).

Table 2: Sample Composition, HRS Households

\begin{tabular}{|c|c|c|c|c|}
\hline & $\begin{array}{c}\text { All } \\
\text { Households, } \\
\text { Head 59-72 }\end{array}$ & $\begin{array}{l}\text { Households } \\
\text { 59-72, with } \\
\text { SS Earnings }\end{array}$ & $\begin{array}{c}\text { Couples } \\
\text { 59-72, } \\
\text { with SS } \\
\text { Earnings }\end{array}$ & $\begin{array}{c}\text { Couples } \\
\text { 63-72, with SS } \\
\text { Earnings }\end{array}$ \\
\hline \multicolumn{5}{|c|}{ Household Head Education Less Than High School } \\
\hline Survey Households & 1579 & 1086 & 540 & 374 \\
\hline Population Counterpart (thousands) & 3769.3 & 2653.4 & 1324.2 & 938.3 \\
\hline \multicolumn{5}{|c|}{ Household Head High School Education and/or Some College } \\
\hline Survey Households & 2793 & 1954 & 1076 & 689 \\
\hline Population Counterpart (thousands) & 7669.2 & 5453.6 & 3013.2 & 1949.3 \\
\hline \multicolumn{5}{|l|}{ Household Head at least College Degree } \\
\hline Survey Households & 1132 & 793 & 526 & 337 \\
\hline Population Counterpart (thousands) & 3411.6 & 2390.6 & 1611.8 & 1013.6 \\
\hline \multicolumn{5}{|l|}{ Total } \\
\hline Survey Households & 5504 & 3833 & 2142 & 1400 \\
\hline Population Counterpart (thousands) & 14850.1 & 10497.6 & 5949.2 & 3901.1 \\
\hline
\end{tabular}


Table 3: Percentage of HRS Households with Top-Coded Earnings, by Education of Household Head, 1951-1979

\begin{tabular}{|c|c|c|c|c|}
\hline Year & Total & $\begin{array}{l}\text { Less than HS } \\
\text { Education }\end{array}$ & $\begin{array}{l}\text { HS or Some } \\
\text { College }\end{array}$ & $\begin{array}{l}\text { College and } \\
\text { Beyond }\end{array}$ \\
\hline 1951 & $7.5 \%$ & $7.7 \%$ & $7.8 \%$ & $6.6 \%$ \\
\hline 1952 & 10.1 & 11.3 & 10.6 & 7.4 \\
\hline 1953 & 14.5 & 17.7 & 14.4 & 10.6 \\
\hline 1954 & 17.3 & 18.9 & 18.4 & 12.8 \\
\hline 1955 & 14.5 & 14.9 & 15.3 & 12.2 \\
\hline 1956 & 18.3 & 16.8 & 20.4 & 15.6 \\
\hline 1957 & 21.5 & 19.1 & 24.4 & 17.9 \\
\hline 1958 & 24.0 & 20.7 & 25.8 & 23.7 \\
\hline 1959 & 22.6 & 18.1 & 24.7 & 23.2 \\
\hline 1960 & 27.6 & 20.2 & 30.3 & 30.1 \\
\hline 1961 & 31.9 & 23.9 & 33.3 & 37.9 \\
\hline 1962 & 39.3 & 28.6 & 41.8 & 45.9 \\
\hline 1963 & 46.2 & 32.8 & 48.9 & 56.0 \\
\hline 1964 & 52.4 & 36.7 & 56.0 & 63.0 \\
\hline 1965 & 60.0 & 42.3 & 63.8 & 71.5 \\
\hline 1966 & 46.9 & 29.7 & 48.7 & 63.5 \\
\hline 1967 & 53.0 & 32.0 & 56.5 & 70.4 \\
\hline 1968 & 46.7 & 26.7 & 48.0 & 67.6 \\
\hline 1969 & 54.4 & 33.7 & 56.4 & 75.2 \\
\hline 1970 & 57.8 & 37.2 & 60.4 & 77.3 \\
\hline 1971 & 61.9 & 41.0 & 65.3 & 79.8 \\
\hline 1972 & 59.6 & 40.3 & 62.2 & 77.1 \\
\hline 1973 & 52.7 & 32.6 & 54.3 & 73.4 \\
\hline 1974 & 42.5 & 22.4 & 42.6 & 66.5 \\
\hline 1975 & 41.4 & 21.2 & 40.8 & 66.5 \\
\hline 1976 & 42.8 & 21.6 & 43.3 & 66.3 \\
\hline 1977 & 43.4 & 23.2 & 44.1 & 65.6 \\
\hline 1978 & 45.5 & 25.3 & 47.7 & 65.0 \\
\hline 1979 & 31.1 & 13.7 & 30.8 & 52.4 \\
\hline
\end{tabular}

Source: Authors' tabulations. 
Table 4: Wealth Distribution for HRS Couples with Husbands Aged 63-72, Normalized to Age $63 / 64$ in Year 2000 (\$000s)

Wealth Component

SSW + Annuity

DB Accumulation

DC Accumulation

Other Financial Assets

Net Housing Equity

Other Wealth

Net Worth

SSW + Annuity

DB Accumulation

DC Accumulation

Other Financial Assets

Net Housing Equity

Other Wealth

Net Worth

SSW + Annuity

DB Accumulation

DC Accumulation

Other Financial Assets

Net Housing Equity

Other Wealth

Net Worth

SSW + Annuity

DB Accumulation

DC Accumulation

Other Financial Assets

Net Housing Equity

Other Wealth

Net Worth

SSW + Annuity

DB Accumulation

DC Accumulation

Other Financial Assets

Net Housing Equity

Other Wealth

Net Worth

SSW + Annuity

DB Accumulation

DC Accumulation

Other Financial Assets

Net Housing Equity

Other Wealth

Net Worth

\author{
Full Sample
}

$\begin{array}{lll}\text { Less Than High } & \text { High School and/or } & \begin{array}{l}\text { College and/or } \\ \text { School Degree }\end{array} \\ \text { Some College } & \text { Postgraduate }\end{array}$

20th percentile

\begin{tabular}{rr}
177.3 & 163.4 \\
0 & 0 \\
0 & 0 \\
0.9 & 0 \\
34.6 & 6.0 \\
6.0 & 2.5 \\
302.0 & 220.9 \\
\multicolumn{3}{c}{ 40th percentile }
\end{tabular}

245.8

$\begin{array}{rr}0 & 0 \\ 8 & 0\end{array}$

$\begin{array}{lr}28.0 & 2.0\end{array}$

$76.5 \quad 45.3$

$\begin{array}{ll}14.0 & 7.2\end{array}$

$450.1 \quad 323.2$

50th percentile - Median

$264.1 \quad 247.9$

0

22.7

58.0

92.6

18.1

536.8

60th percentile

$264.1 \quad 261.4$

0

$\begin{array}{ll}46.5 & 6.9\end{array}$

$105.3 \quad 18.2$

$109.4 \quad 79.6$

$\begin{array}{lr}23.0 & 15.9\end{array}$

$637.4 \quad 441.3$

80th percentile

$329.5 \quad 294.3$

$0 \quad 0$

$148.0 \quad 58.2$

$215.2 \quad 120.0$

$167.3 \quad 113.6$

$40.0 \quad 26.5$

$994.5 \quad 644.1$

Sample Mean

$\begin{array}{rr}251.5 & 229.9 \\ 47.7 & 33.9 \\ 136.4 & 36.7 \\ 199.7 & 69.6 \\ 115.3 & 78.7 \\ 33.0 & 19.2 \\ 783.4 & 468.1\end{array}$

$\begin{array}{rr}188.9 & 165.7 \\ 0 & 0 \\ 0 & 4.2 \\ 1.6 & 29.6 \\ 40.4 & 61.3 \\ 7.4 & 9.6 \\ 315.1 & 448.1 \\ & \\ 246.8 & 270.1 \\ 0 & 0 \\ 8 & 45.0 \\ 28.8 & 110.0 \\ 78.8 & 106.1 \\ 15.9 & 17.5 \\ 450.4 & 707.9 \\ & \\ 264.1 & 286.9 \\ 0 & 0 \\ 20.4 & 81.7 \\ 55.7 & 170.5 \\ 90.9 & 125.0 \\ 20.0 & 21.9 \\ 531.1 & 856.3 \\ & \\ 282.0 & 309.6 \\ 0 & 0 \\ 40.3 & 124.6 \\ 98.0 & 264.3 \\ 104.1 & 153.4 \\ 24.1 & 30.0 \\ 622.1 & 1051.3 \\ & \\ 321.0 & 368.0 \\ 12.0 & 65.1 \\ 118.9 & 349.7 \\ 223.3 & 600.0 \\ 153.1 & 230.8 \\ 39.4 & 59.3 \\ 866.4 & 1598.6 \\ & 330.9 \\ 250.9 & 437.3 \\ 44.4 & 165.7 \\ 83.1 & 524.5 \\ 138.7 & \end{array}$

653.7

Source: Authors' tabulations from the 2000 HRS. DB pension wealth was calculated from the pension wealth imputations from the HRS (March 2005 version). Social security and annuity wealth were computed as in PRVW (2005). 
Table 5: Combined Employer and Employee Contributions to DC Plans, Percentage of Earnings, HRS Married Men with Positive DC Contributions

\begin{tabular}{rrr} 
Decile & Within-Decile Mean & Upper Bound \\
\hline 1 & 1.83 & 2.88 \\
2 & 3.70 & 4.23 \\
3 & 4.81 & 5.28 \\
4 & 5.86 & 6.31 \\
5 & 7.10 & 7.71 \\
6 & 8.54 & 9.00 \\
7 & 9.72 & 10.04 \\
8 & 10.94 & 11.97 \\
9 & 13.30 & 14.91 \\
10 & 17.09 & 31.11
\end{tabular}

Source: Tabulations courtesy of Anil Kumar using 1992 HRS administrative data and the approach outlined in Cunningham, Engelhardt, and Kumar (2006).

Table 6: Distribution of Imputed Number of Jobs During the Working Career, Stratified by Education Level of HRS Respondent

$\begin{array}{lllll}\text { Number of Jobs } & \begin{array}{l}\text { All Education } \\ \text { Levels }\end{array} & \begin{array}{l}\text { Less Than High } \\ \text { School Degree }\end{array} & \begin{array}{l}\text { High School } \\ \text { and/or Some } \\ \text { College }\end{array} & \begin{array}{l}\text { College and/or } \\ \text { Postgraduate }\end{array} \\ 0 & 31 & 14 & 12 & 5 \\ 1 & 1081 & 286 & 533 & 262 \\ 2 & 257 & 65 & 127 & 65 \\ 3 & 31 & 9 & 17 & 5\end{array}$

Source: Authors' imputations for husbands in HRS couples, using algorithm describe in the text.

Table 7: Distribution of Job Lengths for Jobs Imputed Number of Jobs During the Working Career, Stratified by Education Level of HRS Respondent Distribution of Job Lengths, by Education Level of Individual

$\begin{array}{llll} & \text { Less Than High } & \text { High School and/or } & \text { College and/or } \\ \text { School Degree } & \text { Some College } & \text { Postgraduate } \\ 10 \% & 6 & 6 & 6 \\ 25 \% & 11 & 12 & 12 \\ 50 \% & 25 & 27 & 24 \\ 75 \% & 33 & 34 & 34 \\ 90 \% & 35 & 35 & 35 \\ \text { Mean } & 22.3 & 22.8 & 22.4\end{array}$

Source: Authors' imputations using algorithm described in the text. 
Table 8: Distribution of DC Plan Balances at Retirement (\$2000) Simulating Using IndividualSpecific Draws from the Distribution of DC Contribution Rates as a Share of Pay

\begin{tabular}{|c|c|c|c|c|c|c|}
\hline \multirow{4}{*}{$\begin{array}{l}\text { Investment } \\
\text { Strategy/ } \\
\text { Percentile }\end{array}$} & \multicolumn{3}{|c|}{ Empirical Stock Returns } & \multicolumn{3}{|c|}{ Empirical Returns Reduced 300 Basis Points } \\
\hline & \multirow{3}{*}{$\begin{array}{c}\text { Less Than } \\
\text { High School } \\
\text { Degree }\end{array}$} & \multirow{3}{*}{$\begin{array}{l}\text { High School } \\
\text { and/or Some } \\
\text { College }\end{array}$} & \multirow{3}{*}{$\begin{array}{c}\text { College } \\
\text { and/or } \\
\text { Postgraduate }\end{array}$} & \multirow{3}{*}{$\begin{array}{c}\text { Less Than } \\
\text { High School } \\
\text { Degree }\end{array}$} & \multirow{3}{*}{$\begin{array}{l}\text { High School } \\
\text { and/or Some } \\
\text { College }\end{array}$} & \multirow{3}{*}{$\begin{array}{c}\text { College } \\
\text { and/or } \\
\text { Postgraduate }\end{array}$} \\
\hline & & & & & & \\
\hline & & & & & & \\
\hline \multicolumn{7}{|l|}{$100 \%$ TIPS } \\
\hline 1 & 27.3 & 39.1 & 55.5 & 27.3 & 39.1 & 55.5 \\
\hline 10 & 41.9 & 58.6 & 85.6 & 41.9 & 58.6 & 85.6 \\
\hline 50 & 117.1 & 167.4 & 236.0 & 117.1 & 167.4 & 236.0 \\
\hline 90 & 225.7 & 325.5 & 462.7 & 225.7 & 325.5 & 462.7 \\
\hline Mean & 123.7 & 177.0 & 251.6 & 123.7 & 177.0 & 251.6 \\
\hline \multicolumn{7}{|c|}{$100 \%$ Nominal Government Bonds } \\
\hline 1 & 18.2 & 26.1 & 37.9 & 18.2 & 26.1 & 37.9 \\
\hline 10 & 41.2 & 58.7 & 83.9 & 41.2 & 58.7 & 83.9 \\
\hline 50 & 123.1 & 176.2 & 249.8 & 123.1 & 176.2 & 249.8 \\
\hline 90 & 286.0 & 410.9 & 571.8 & 286.0 & 410.9 & 571.8 \\
\hline Mean & 148.8 & 213.4 & 299.4 & 148.8 & 213.4 & 299.4 \\
\hline \multicolumn{7}{|l|}{$100 \%$ Stocks } \\
\hline 1 & 27.3 & 39.3 & 55.2 & 14.9 & 21.2 & 31.2 \\
\hline 10 & 88.1 & 127.0 & 173.4 & 46.3 & 66.3 & 94.6 \\
\hline 50 & 367.1 & 533.3 & 705.4 & 186.5 & 268.5 & 370.5 \\
\hline 90 & 1411.5 & 2066.0 & 2640.9 & 695.8 & 1008.1 & 1335.9 \\
\hline Mean & 627.7 & 918.9 & 1182.5 & 312.0 & 452.3 & 604.3 \\
\hline \multicolumn{7}{|c|}{$50 \%$ Stocks, $50 \%$ TIPS } \\
\hline 1 & 31.7 & 45.5 & 63.3 & 23.1 & 33.1 & 47.1 \\
\hline 10 & 73.0 & 105.2 & 143.9 & 52.8 & 75.8 & 106.0 \\
\hline 50 & 222.5 & 321.0 & 436.6 & 160.4 & 230.5 & 320.5 \\
\hline 90 & 525.5 & 760.6 & 1017.7 & 376.0 & 541.6 & 740.2 \\
\hline Mean & 270.5 & 391.1 & 526.8 & 194.2 & 279.5 & 384.7 \\
\hline \multicolumn{7}{|c|}{$50 \%$ Stocks, $50 \%$ Nominal Bonds } \\
\hline 1 & 29.6 & 42.7 & 59.6 & 21.6 & 31.1 & 44.4 \\
\hline 10 & 73.6 & 105.8 & 145.4 & 53.3 & 76.4 & 107.2 \\
\hline 50 & 233.3 & 336.6 & 457.0 & 167.9 & 241.2 & 334.8 \\
\hline 90 & 601.0 & 871.4 & 1156.6 & 428.3 & 617.9 & 837.1 \\
\hline Mean & 299.0 & 433.0 & 579.9 & 214.0 & 308.4 & 421.9 \\
\hline \multicolumn{7}{|c|}{ Empirical Lifecycle, Stocks and TIPS } \\
\hline 1 & 30.1 & 43.1 & 60.3 & 21.2 & 30.2 & 43.6 \\
\hline 10 & 72.3 & 104.2 & 142.5 & 50.0 & 71.6 & 100.8 \\
\hline 50 & 225.1 & 325.4 & 439.9 & 153.9 & 221.1 & 307.8 \\
\hline 90 & 564.5 & 820.9 & 1081.2 & 377.9 & 545.5 & 739.5 \\
\hline Mean & 284.1 & 412.7 & 548.6 & 191.8 & 276.7 & 378.9 \\
\hline \multicolumn{7}{|c|}{ Empirical Lifecycle, Stocks and Nominal Bonds } \\
\hline 1 & 28.2 & 40.5 & 56.7 & 19.9 & 28.4 & 41.0 \\
\hline 10 & 71.8 & 103.3 & 141.8 & 49.7 & 71.1 & 100.4 \\
\hline 50 & 232.2 & 335.6 & 453.1 & 158.5 & 227.6 & 316.6 \\
\hline 90 & 626.5 & 912.8 & 1196.6 & 418.4 & 605.1 & 816.4 \\
\hline Mean & 307.0 & 446.3 & 591.5 & 206.8 & 298.5 & 407.3 \\
\hline
\end{tabular}

Source: Authors' tabulations of simulation results. See text for further details. 
Table 9: Distribution of DC Plan Balances at Retirement Assuming All Individuals Contribute to Plan at Average Contribution Rate (\$2000)

\begin{tabular}{|c|c|c|c|c|c|c|}
\hline \multirow{4}{*}{$\begin{array}{l}\text { Investment } \\
\text { Strategy/ } \\
\text { Percentile }\end{array}$} & \multicolumn{3}{|c|}{ Empirical Stock Returns } & \multicolumn{3}{|c|}{ Empirical Returns Reduced 300 Basis Points } \\
\hline & \multirow{3}{*}{$\begin{array}{l}\text { Less Than } \\
\text { High School } \\
\text { Degree }\end{array}$} & \multirow{3}{*}{$\begin{array}{l}\text { High School } \\
\text { and/or Some } \\
\text { College }\end{array}$} & \multirow{3}{*}{$\begin{array}{c}\text { College } \\
\text { and/or } \\
\text { Postgraduate }\end{array}$} & \multirow{3}{*}{$\begin{array}{c}\text { Less Than } \\
\text { High School } \\
\text { Degree }\end{array}$} & \multirow{3}{*}{$\begin{array}{l}\text { High School } \\
\text { and/or Some } \\
\text { College }\end{array}$} & \multirow{3}{*}{$\begin{array}{c}\text { College } \\
\text { and/or } \\
\text { Postgraduate }\end{array}$} \\
\hline & & & & & & \\
\hline & & & & & & \\
\hline $100 \%$ TIPS & 123.7 & 177.0 & 251.5 & 123.7 & 177.0 & 251.5 \\
\hline \multicolumn{7}{|c|}{$100 \%$ Nominal Government Bonds } \\
\hline 1 & 57.7 & 82.1 & 122.1 & 57.7 & 82.1 & 122.1 \\
\hline 10 & 82.8 & 118.2 & 171.7 & 82.8 & 118.2 & 171.7 \\
\hline 50 & 135.1 & 193.4 & 273.4 & 135.1 & 193.4 & 273.4 \\
\hline 90 & 230.9 & 332.1 & 457.4 & 230.9 & 332.1 & 457.4 \\
\hline Mean & 148.8 & 213.4 & 299.3 & 148.8 & 213.4 & 299.3 \\
\hline \multicolumn{7}{|l|}{$100 \%$ Stocks } \\
\hline 1 & 58.4 & 83.8 & 120.4 & 32.7 & 46.7 & 70.5 \\
\hline 10 & 138.7 & 199.7 & 276.1 & 73.8 & 105.4 & 153.0 \\
\hline 50 & 422.3 & 613.8 & 809.1 & 213.8 & 307.8 & 423.0 \\
\hline 90 & 1321.9 & 1936.9 & 2457.3 & 648.6 & 940.4 & 1235.4 \\
\hline Mean & 627.9 & 919.0 & 1181.8 & 312.1 & 452.3 & 604.0 \\
\hline \multicolumn{7}{|c|}{$50 \%$ Stocks, $50 \%$ TIPS } \\
\hline 1 & 93.6 & 134.3 & 190.5 & 69.1 & 98.9 & 143.7 \\
\hline 10 & 144.1 & 207.0 & 287.8 & 105.1 & 150.4 & 214.0 \\
\hline 50 & 246.8 & 356.4 & 483.1 & 177.7 & 255.5 & 354.1 \\
\hline 90 & 426.0 & 617.5 & 818.4 & 303.5 & 437.8 & 592.1 \\
\hline Mean & 270.5 & 391.2 & 526.6 & 194.2 & 279.5 & 384.6 \\
\hline \multicolumn{7}{|c|}{$50 \%$ Stocks, $50 \%$ Nominal Bonds } \\
\hline 1 & 81.9 & 117.3 & 167.4 & 60.6 & 86.6 & 126.7 \\
\hline 10 & 136.2 & 195.7 & 272.8 & 99.4 & 142.3 & 203.1 \\
\hline 50 & 260.8 & 376.5 & 509.3 & 187.4 & 269.4 & 372.4 \\
\hline 90 & 507.5 & 737.1 & 968.8 & 360.3 & 520.7 & 698.0 \\
\hline Mean & 299.1 & 433.1 & 579.6 & 214.0 & 308.5 & 421.7 \\
\hline \multicolumn{7}{|c|}{ Empirical Lifecycle, Stocks and TIPS } \\
\hline 1 & 86.4 & 123.5 & 177.7 & 62.4 & 88.9 & 131.8 \\
\hline 10 & 137.1 & 196.8 & 275.1 & 96.4 & 137.6 & 198.4 \\
\hline 50 & 250.2 & 362.2 & 487.0 & 170.5 & 245.1 & 339.6 \\
\hline 90 & 471.2 & 687.7 & 894.1 & 312.6 & 452.8 & 605.2 \\
\hline Mean & 284.2 & 412.8 & 548.4 & 191.9 & 276.7 & 378.7 \\
\hline \multicolumn{7}{|c|}{ Empirical Lifecycle, Stocks and Nominal Bonds } \\
\hline 1 & 76.2 & 109.2 & 157.1 & 55.1 & 78.5 & 116.6 \\
\hline 10 & 129.8 & 186.4 & 260.6 & 91.1 & 130.1 & 187.8 \\
\hline 50 & 259.9 & 376.1 & 505.5 & 176.9 & 254.2 & 352.1 \\
\hline 90 & 538.6 & 786.5 & 1020.7 & 357.2 & 517.6 & 690.0 \\
\hline Mean & 307.1 & 446.4 & 591.2 & 206.8 & 298.6 & 407.1 \\
\hline
\end{tabular}

Source: Authors' tabulations of simulation results. See text for further details. 
Table 10: Certainty Equivalent Wealth (\$2000) of DC Plan Accumulation Simulated Using Individual-Specific Draws from the Distribution of DC Contribution Rates as a Share of Pay and Defining "Non-DC Wealth" as Sum of Non-Retirement Financial Assets, Social Security Wealth and Annuity Income

\begin{tabular}{|c|c|c|c|c|c|c|}
\hline & \multicolumn{3}{|c|}{ Empirical Stock Returns } & \multicolumn{3}{|c|}{$\begin{array}{l}\text { Empirical Stock Returns, } \\
\text { Reduced } 300 \text { Basis Points }\end{array}$} \\
\hline & $\begin{array}{l}\text { Less } \\
\text { Than HS } \\
\text { Degree }\end{array}$ & $\begin{array}{l}\text { HS and/or } \\
\text { Some } \\
\text { College }\end{array}$ & $\begin{array}{l}\text { College } \\
\text { or Post- } \\
\text { graduate }\end{array}$ & $\begin{array}{l}\text { Less Than } \\
\text { HS } \\
\text { Degree }\end{array}$ & $\begin{array}{l}\text { HS } \\
\text { and/or } \\
\text { Some } \\
\text { College }\end{array}$ & $\begin{array}{l}\text { College } \\
\text { or Post- } \\
\text { graduate }\end{array}$ \\
\hline \multicolumn{7}{|l|}{$\alpha=0$} \\
\hline $100 \%$ TIPS & 123.7 & 177.0 & 251.6 & & & \\
\hline $100 \%$ Government Bonds & 148.8 & 213.4 & 299.4 & & & \\
\hline $100 \%$ Stocks & 627.7 & 918.9 & 1182.5 & 312.0 & 452.3 & 604.3 \\
\hline $50 \%$ Stocks, $50 \%$ TIPS & 270.5 & 391.1 & 526.8 & 194.2 & 279.5 & 384.7 \\
\hline $50 \%$ Stocks, $50 \%$ Bonds & 299.0 & 433.0 & 579.9 & 214.0 & 308.4 & 421.9 \\
\hline Empirical Lifecycle, Stocks and TIPS & 284.1 & 412.7 & 548.6 & 191.8 & 276.7 & 378.9 \\
\hline Empirical Lifecycle, Stocks and Bonds & 307.0 & 446.3 & 591.5 & 206.8 & 298.5 & 407.3 \\
\hline \multicolumn{7}{|l|}{$\alpha=1$} \\
\hline $100 \%$ TIPS & 117.5 & 167.9 & 239.0 & & & \\
\hline $100 \%$ Government Bonds & 135.9 & 194.3 & 274.3 & & & \\
\hline $100 \%$ Stocks & 439.9 & 635.8 & 846.9 & 237.1 & 340.0 & 467.6 \\
\hline $50 \%$ Stocks, $50 \%$ TIPS & 239.2 & 344.3 & 468.4 & 175.0 & 250.9 & 348.1 \\
\hline $50 \%$ Stocks, $50 \%$ Bonds & 257.1 & 370.2 & 502.5 & 188.2 & 269.9 & 373.4 \\
\hline Empirical Lifecycle, Stocks and TIPS & 246.7 & 356.1 & 480.4 & 171.2 & 245.7 & 340.1 \\
\hline Empirical Lifecycle, Stocks and Bonds & 260.0 & 375.3 & 505.9 & 180.7 & 259.2 & 358.4 \\
\hline \multicolumn{7}{|l|}{$\alpha=2$} \\
\hline $100 \%$ TIPS & 111.6 & 159.1 & 226.7 & & & \\
\hline $100 \%$ Government Bonds & 125.0 & 178.2 & 252.8 & & & \\
\hline $100 \%$ Stocks & 333.6 & 477.9 & 653.4 & 192.2 & 273.9 & 384.1 \\
\hline $50 \%$ Stocks, $50 \%$ TIPS & 213.1 & 305.5 & 419.4 & 158.8 & 226.9 & 316.9 \\
\hline $50 \%$ Stocks, $50 \%$ Bonds & 224.4 & 321.5 & 441.5 & 167.7 & 239.6 & 334.3 \\
\hline Empirical Lifecycle, Stocks and TIPS & 217.0 & 311.6 & 425.5 & 154.3 & 220.6 & 308.1 \\
\hline Empirical Lifecycle, Stocks and Bonds & 224.7 & 322.4 & 440.7 & 160.4 & 229.1 & 320.1 \\
\hline \multicolumn{7}{|l|}{$\alpha=4$} \\
\hline $100 \%$ TIPS & 100.8 & 143.2 & 204.6 & & & \\
\hline $100 \%$ Government Bonds & 108.0 & 153.2 & 219.3 & & & \\
\hline $100 \%$ Stocks & 227.5 & 322.8 & 456.2 & 143.0 & 202.3 & 290.7 \\
\hline $50 \%$ Stocks, $50 \%$ TIPS & 174.2 & 248.2 & 346.0 & 133.9 & 190.3 & 269.0 \\
\hline $50 \%$ Stocks, $50 \%$ Bonds & 178.9 & 254.5 & 355.8 & 138.2 & 196.3 & 277.9 \\
\hline Empirical Lifecycle, Stocks and TIPS & 174.9 & 249.2 & 346.8 & 129.4 & 183.8 & 260.3 \\
\hline Empirical Lifecycle, Stocks and Bonds & 177.3 & 252.3 & 352.3 & 131.9 & 187.2 & 265.7 \\
\hline
\end{tabular}

Source: Authors' tabulations from simulation analysis. See text for further discussion. 
Table 11: Distribution of Defined Benefit Pension Values at Retirement (\$000s measured in \$2000)

\begin{tabular}{|c|c|c|c|c|c|c|}
\hline \multirow{4}{*}{ Percentile } & \multicolumn{3}{|c|}{ Private Sector Plans } & \multicolumn{3}{|c|}{ Public Sector Plans } \\
\hline & $\begin{array}{l}\text { Less Than } \\
\text { Ling }\end{array}$ & High School & College & Less Than & High School & College \\
\hline & High School & and/or Some & and/or & & and/or some & $\begin{array}{c}\text { and/or } \\
\text { Postoraduate }\end{array}$ \\
\hline & Degree & College & Postgraduate & $\begin{array}{l}\text { School } \\
\text { Degree }\end{array}$ & & Postgraduate \\
\hline 1 & 51.6 & 60.4 & 67.1 & 35.8 & 40.1 & 40.4 \\
\hline 10 & 67.3 & 86.6 & 108.3 & 134.6 & 186.7 & 322.5 \\
\hline 50 & 110.1 & 150.6 & 260.1 & 232.0 & 326.8 & 563.4 \\
\hline 90 & 185.1 & 237.4 & 406.5 & 303.3 & 424.8 & 734.7 \\
\hline Mean & 118.0 & 156.0 & 255.5 & 226.7 & 316.8 & 544.7 \\
\hline
\end{tabular}

Source: Authors' tabulations of simulation results. See text for further details.

Table 12: Certainty Equivalent Wealth (000s of \$2000) of DB Plan Accumulation with "Non-DB Wealth" Defined to Include Non-Retirement Financial Assets, Social Security Wealth and Annuity Income

\begin{tabular}{|c|c|c|c|c|c|c|}
\hline & \multicolumn{3}{|c|}{ Private Sector Plans } & \multicolumn{3}{|c|}{ Public Sector Plans } \\
\hline & & $\mathrm{HS}$ & & & $\mathrm{HS}$ & \\
\hline & Less & and/or & College & Less & and/or & College \\
\hline & Than HS & Some & or Post- & Than HS & Some & or Post- \\
\hline Risk Aversion & Degree & College & graduate & Degree & College & graduate \\
\hline$\alpha=0$ & 118.0 & 156.0 & 255.5 & 226.7 & 316.8 & 544.7 \\
\hline$\alpha=1$ & 114.8 & 151.6 & 242.5 & 220.5 & 307.4 & 524.1 \\
\hline$\alpha=2$ & 111.9 & 147.6 & 229.9 & 212.7 & 294.7 & 491.5 \\
\hline$\alpha=4$ & 106.6 & 140.3 & 208.6 & 193.6 & 264.7 & 417.0 \\
\hline
\end{tabular}

Source: Authors' tabulations from simulation analysis. See text for further discussion. 
Figure 1a: DB Participation Rate in the SIPP, Every Other Cohort

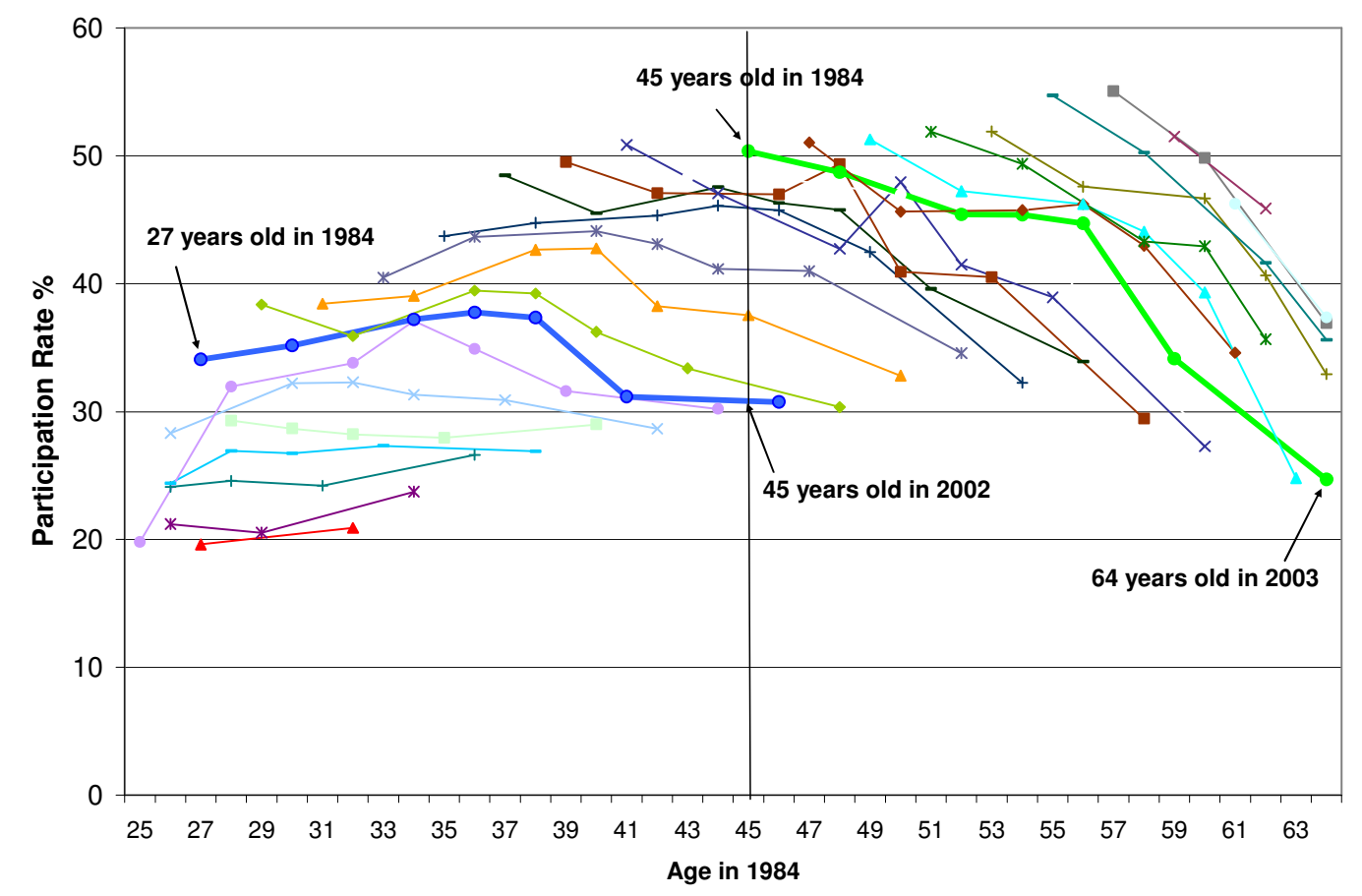

Figure 1b: DC Participation Rate in the SIPP, Every Other Cohort

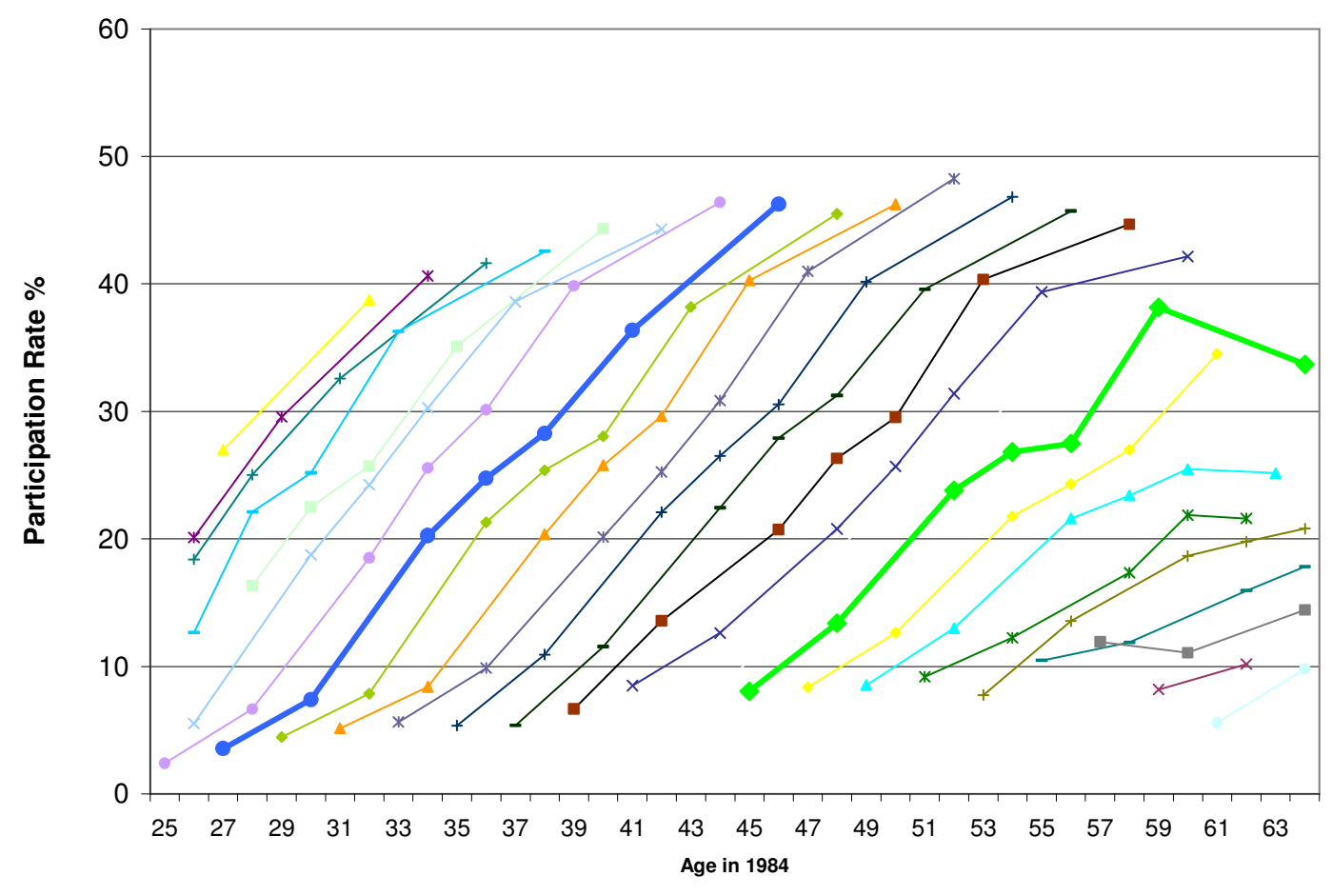


Figure 2a: $25^{\text {th }}$ Percentile Earnings, After Top-Coding Correction, HRS Husbands

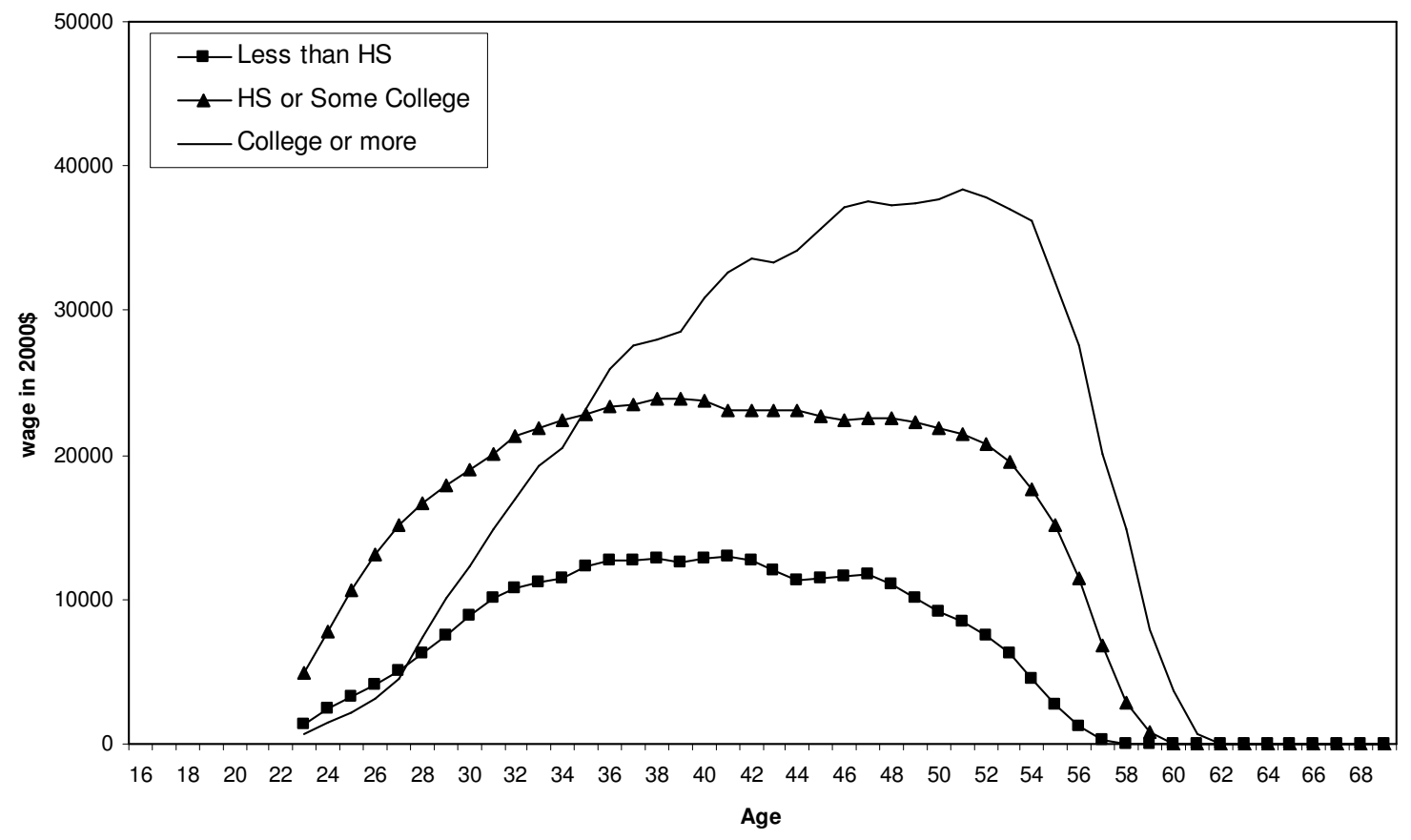

Figure 2b: 50 $^{\text {th }}$ Percentile Earnings, After Top-Coding Correction, HRS Husbands

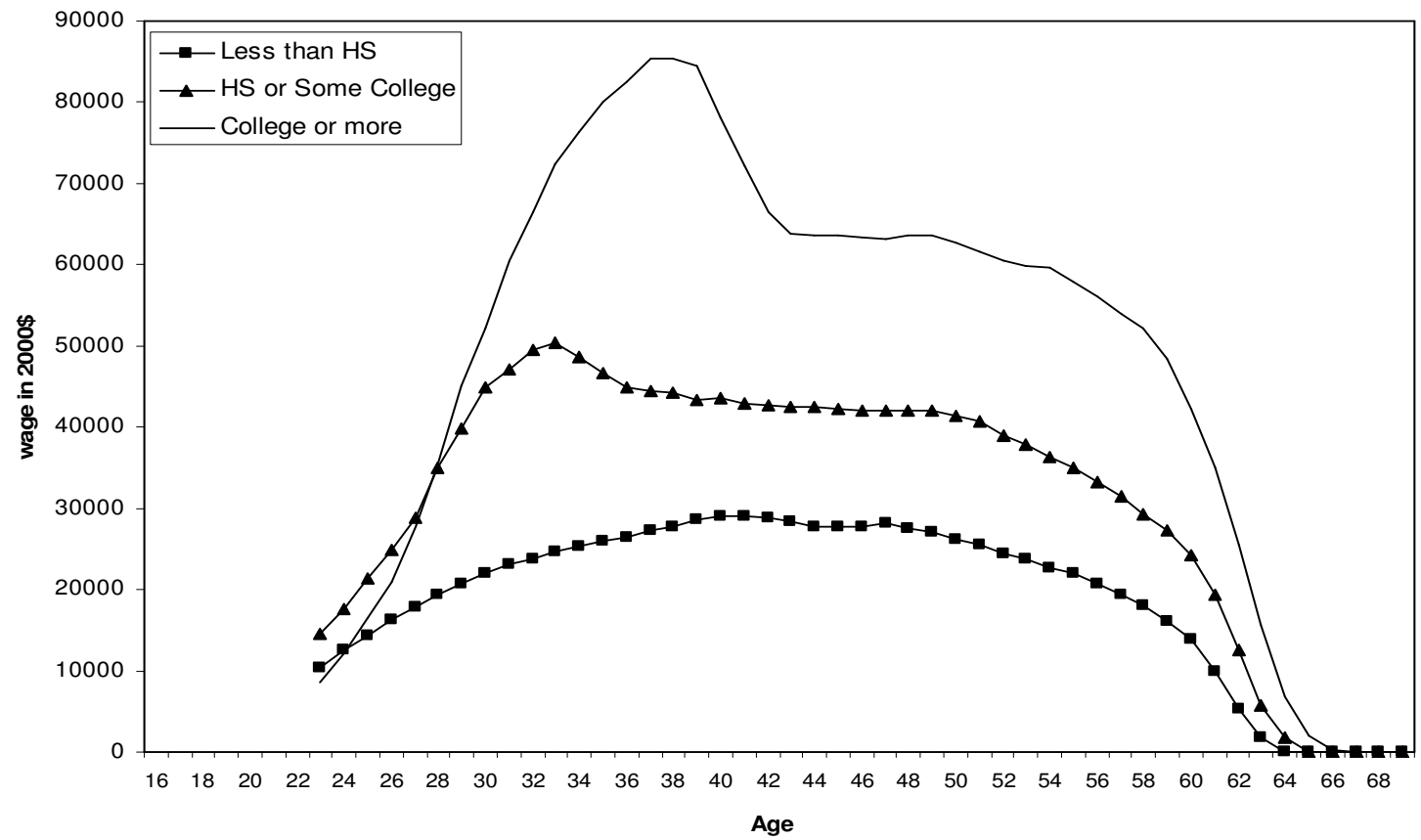


Figure 2c: $7^{\text {th }}$ Percentile Earnings, After Top-Coding Correction, HRS Husbands

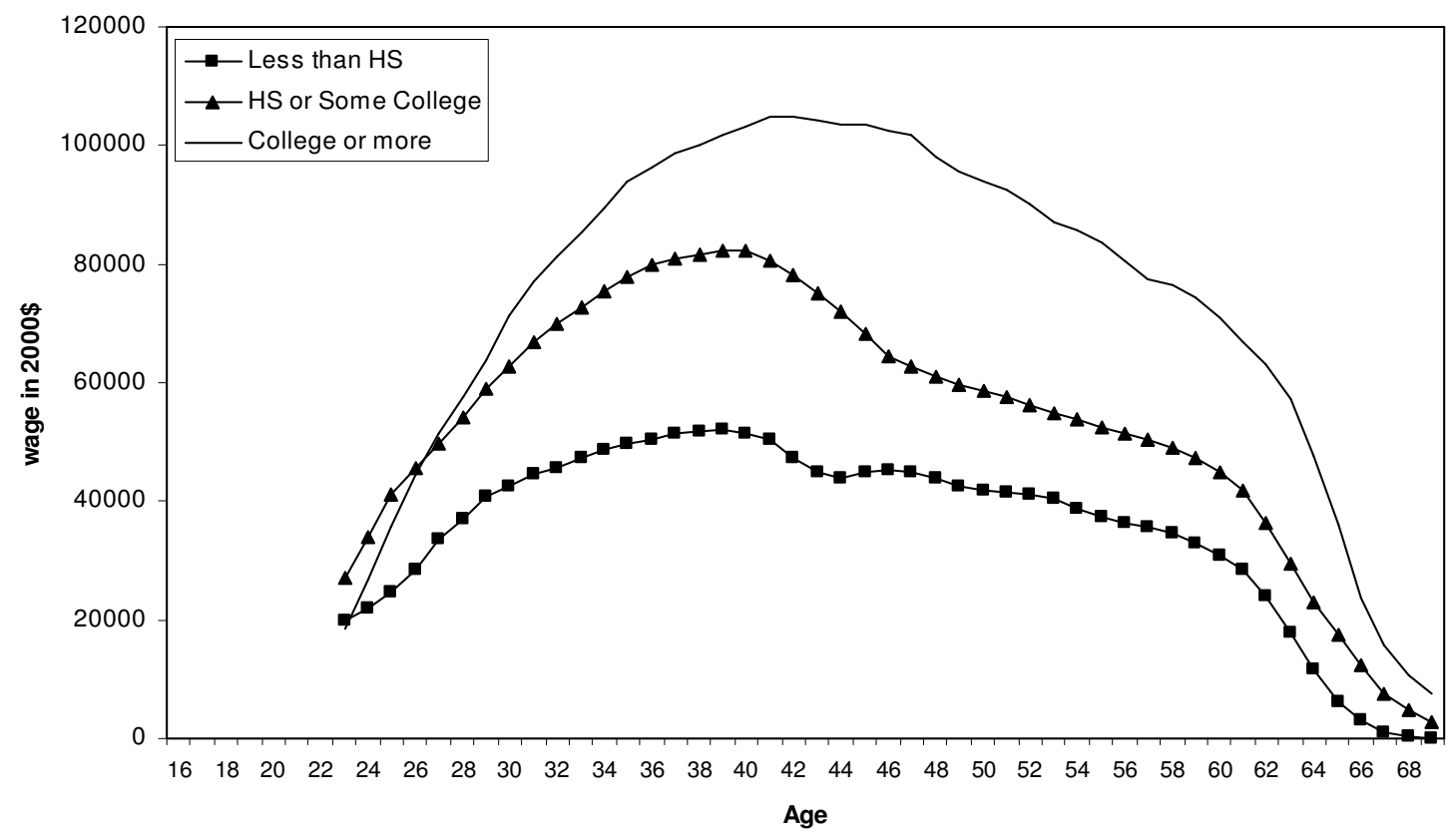

